\title{
Making Itself at Home
}

\section{Understanding Foreign Law in Domestic Jurisprudence: The Indian Case}

\author{
By \\ Adam M. Smith ${ }^{*}$
}

I.

INTRODUCTION

At first glance, it seems that few judicial debates better illustrate the uniqueness of modern American legal thinking than discussions of foreign law in domestic courts, specifically in constitutional decisions. While an accepted, ${ }^{1}$

- Chayes Fellow, Harvard Law School.

This article was begun while the author was a visitor at the South Asia Human Rights Documentation Centre in Delhi, India and he thanks Ravi Nair and his team for making his stay so fruitful. At Harvard, thanks go to Ryan Goodman, Jim Cavallaro, and the Human Rights Programwhich funded the work-for making the trip a reality. The paper was expanded and greatly improved through the advice and edits of Justice Richard Goldstone, whose comparative constitutionalism seminar during Spring 2005 provided a base for further work. For their sage advice and criticism, thanks also go to Rosalind Dixon, Rachel Rebouche, Matthew Price, Tanya Goldman and, of course, Julie Gold. Finally, the author expresses his appreciation to the professional editing team at BJIL. Naturally, all errors remain the author's alone.

1. Courts throughout the world regularly cite other countries' precedents, international covenants (both those to which their countries are signatories and those to which they are not) and/or non-municipal legal theories/canons of construction in making their judgments. A partial list of countries at the vanguard of this internationalization movement includes: Australia (Plaintiff S157/2002 v. The Commonwealth (2003) 211 C.L.R. 476 (citing precedents from the European Court of Human Rights, New Zealand, and the United States in establishing judicial review over governmental immigration decisions)); New Zealand (Hosking v. Runting, [2004] 1 N.Z.L.R. 1 (H.C.) (referring to the American Law Institute's Restatement of Torts)); England ( $R$ [on the application of DJ] v. Mental Health Review Tribunal (2005) All E.R. 71 (Mental Health Review Tribunals) (citing United States case law regarding the discharge of mentally ill patients)); Ireland ((K.C.) v. K.(J.) [2004] 1 I.R. 224 (Ir.) (referring to Canadian Supreme Court and American state court case law regarding divorce law)); France (Chappaz c/ Aussedat, Cour de cassation, Première chambre civile [Cass. le civ.] [highest court of ordinary jurisdiction], 12 mai 2004, Bull. civ. 2004, I No. 01-14.259 et 01-14.931 FS-P (Fr.) (citing American precedent in regard to limited liability for civil aviation accidents)); Hungary (Decision 36/1994, VI.24 AB (citing the ECHR practice regarding the definition of libel)); Israel (HCJ 2056/04 Beit Sourik Village Council v. Government of Israel [2004] IsrSC, available at http://elyon1 .court.gov.il/eng/verdict/framesetSrch.html (basing its opinion partly on tenets of 'customary international law')); Nigeria (Kalu v. State, [1998] 12 
encouraged, ${ }^{2}$ or even mandated ${ }^{3}$ practice in many other national jurisdictions, the mere reference to foreign or international law-let alone reliance on nondomestic laws, practices, or mores as persuasive precedent by an American jurist-raises the ire of a large school of judges, politicians, and academics who firmly reject the relevance and appropriateness of applying foreign legal principles to American disputes. ${ }^{4}$ The current political climate, coupled with the present membership of the federal judiciary-particularly the Supreme Courthave made this discussion very charged. The rise of globalization, the polarization of domestic politics, the heavy presence of "foreign" matters on the Supreme Court's docket, ${ }^{5}$ and the steady legal amalgamation of the European

S.C.N.J. I (Nigeria) (citing decisions from several states and international instruments in determining the legality of the death penalty)); Argentina, ("Salgado c/Gobierno de la Ciudad de Buenos Aires," (2001) (Arg.) [826/01] (citing U.S. case law in determining if age was a "suspect" class)); Lithuania (Constitutional Court Case no. $2 / 98$ (1998) "On the Death Penalty Provided for by the Sanction of Article 105 of the Criminal Code," available at http://www.lrkt.lt/dokumentai/1998/n8a1209a.htm (citing in support of its decision United Nations and European Council declarations to which Lithuania was not a party)); Malaysia (Pet Far Eastern v. Tay Young Haut, [1999] 5 M.L.J. 558 (relying on the ALI's Restatement of the Law of Restitution, Quasi Contracts and Constructive Trusts)); Tanzania (Republic v. Mbushuu, [1994] T.L.R. 146 [Tanzan. High Ct.] (citing international human rights instruments regarding the death penalty)); Japan (Bortz v. Suzuki, No. 332 Civ. (Shizuoka Dist. Ct., Oct. 12, 1999) (relying heavily on the International Convention for Elimination of all Forms of Racial Discrimination-even though the treaty had not been ratified by Parliament)); Namibia (Mwellie v. Ministry of Works [1995] 9 B.C.L.R. 1118 (citing American, Canadian, and European case law in determining the parameters of "equality")); Singapore (Sebel Furniture Ltd. v. Tiong Hin Engineering, [1999] 2 S.L.R. 662 (referring to American and English precedents on the issue of copyright)).

2. The Canadian Charter of Rights and Freedoms implies a role for foreign precedent by declaring that "[the] Canadian Charter of Rights and Freedoms guarantees the rights and freedoms set out in it subject only to such reasonable limits prescribed by law as can be demonstrably justified in a free and democratic society." Canadian Charter of Rights and Freedoms, Part I of the Constitution Act, 1982, being Schedule B to the Canada Act 1982, ch. 11 , art. 1 (U.K.).

3. When interpreting the country's Bill of Rights, Article 39 of the South African Constitution explicitly permits the country's courts to look to foreign jurisprudence and mandates that they consult international law. S. AFR. CONST. 1996, art. 39(1).

4. At the extremes of this school lie politicians who have attempted to promulgate legislation barring foreign references and/or impeach judges who deign to reference foreign law. See, e.g., Dana Milbank, And the Verdict on Justice Kennedy Is: Guilty, WASH. POST, Apr. 9, 2005, at A3 (describing how "Michael P. Farris, chairman of the Home School Legal Defense Association, said that Kennedy 'should be the poster boy for impeachment' for citing international norms in his opinions. 'If our congressmen and senators do not have the courage to impeach and remove from office Justice Kennedy [for his use of foreign opinions], they ought to be impeached as well."'); Congressman Tom Feeney, Should Americans Be Governed By the Laws of Jamaica, India, Zimbabwe, or the European Union?, http://www.house.gov/feeney/reaffirmation.htm (last visited Apr. 28, 2005); Conservative Alerts, Stop Courts From Using Foreign Law to Interpret U.S. Constitution! Tell Congress to Support the "Reaffirmation of American Independence Resolution," http://capwiz.com/sicminc/issues/alert/?alertid $=8078481$ \&type $=$ CO (last visited Nov. 17, 2005). See also S. Res. 92, 109th Cong. (2005); Constitution Restoration Act of 2004, S. 2323 / H.R. 3799, 108th Cong. $\S 201$ (2004); H.R. Res. 568, 108th Cong. (2004). House Resolution 97, entitled the "Reaffirming American Independence Resolution," argues that "inappropriate judicial reliance on foreign judgments, laws, or pronouncments [sic] threatens the sovereignty of the United States, the separation of powers and the President's and the Senate's treaty-making authority." H.R. Res. 97, 109th Cong. $\S 2$ (2005).

5. Breyer notes that the Court's 2004 term included cases on the Warsaw Convention, cases with Ecuadorian plaintiffs and Dutch defendants, and cases involving the "European cartel 
states with which the United States is most aligned, are likely culprits in bringing this issue to the forefront of American legal scholarship and political debate.

However, while the intensity of the debate has been unequaled elsewhere, it is a mistake to brand this discussion an idiosyncrasy of the modern American system. As this paper will demonstrate, the current debate in the United States in many ways replicates both the historic and current discussions in other parts of the world regarding the use of foreign law. At different times and in different places, judges, politicians, and others have expressed various concerns. There is evidence that, from as early as the fourteenth century, the Irish worried about the encroachment of English law into their system, ${ }^{6}$ a concern that remains today. ${ }^{7}$ In the nineteenth century, the growing hegemony of Germanic legal thinking throughout Europe led to a vigorous reaction against Teutonic law, ${ }^{8}$ and more recently, in countries as varied as Switzerland, ${ }^{9}$ Indonesia, ${ }^{10}$ and Italy, ${ }^{11}$ and in courts as old as the English Privy Council, ${ }^{12}$ anxieties have manifested regarding the "imperialistic justice"13 of American law, instigating an attempt by courts and legislatures to stem the flow of United States precedent.

Meanwhile, the academic contribution to the foreign law discussion has expanded the boundaries even further, with scholarship regarding the rise of world constitutionalism, ${ }^{14}$ the virtues and limits of various forms of

authority." Transcript of Discussion Between U.S. Supreme Court Justices Antonin Scalia and Stephen Breyer, American University Washington College of Law, Jan. 13, 2005 [hereinafter Scalia/Breyer Debate], http://domino.american.edu/AU/media/mediarel.nsf/0/1F2F7DC475

7FD01E85256F890068E6E0?OpenDocument (last visited Apr. 26, 2005).

6. This concern was mutual, with the English also worrying about losing out to Irish law. The 1366 Statutes of Kilkenny, which, inter alia, forbade English colonialists in Ireland from using indigenous Irish legal structures, were a result of these fears. See EDMUND CURTIS, A HISTORY OF IRELAND 113-15 (1950).

7. In Wyatt v. McLoughlin, the Irish Supreme Court set Irish legal interpretations apart, holding that the Court was "not at all concerned with the construction of English law," even if it related to the matter at hand. [1974] I.R. 378, 392 (Ir.).

8. Of note is the broad-based concern that prevailed in nineteenth-century Europe regarding the hegemony of German jurisprudence and the influence of Teutonic models and precedents. The French in particular were weary of succumbing to this German "wave." See Eric H. Reiter, Imported Books, Imported Ideas: Reading European Jurisprudence in Mid-Nineteenth-Century Quebec, 22 LAW \& HIST. REV. 445, 467 (2004).

9. Wolfgang Wiegand, The Reception of American Law in Europe, 39 AM. J. COMP. L. 229, $239,248(1991)$.

10. Stacey Steele, The New Law on Bankruptcy in Indonesia: Towards a Modern Corporate Bankruptcy Regime?, 23 MELB. U.L. REV. 144, 146 (1999).

11. See generally Elisabetta Grande, Italian Criminal Justice: Borrowing and Resistance, 48 AM. J. COMP. L. 227 (2000).

12. For example, in the early 1980 s, "there was a backlash by the Judicial Committee of the Privy Council against the overseas use of American constitutional law." Anthony Lester, The Overseas Trade in the American Bill of Rights, 88 COLUM. L. REV. 537, 542 (1988).

13. Wiegand, supra note 9 , at 239 . Heinz Klug notes a general, broadly expressed fear regarding the American hegemony of global legal structures. See Heinz Klug, Model and AntiModel: The United States Constitution and the "Rise of World Constitutionalism", 2000 WIS. L. REV. 597 (2000).

14. See, e.g., Bruce Ackerman, The Rise of World Constitutionalism, 83 VA. L. REV. 771 (1997). 
"transjudicial" communications, ${ }^{15}$ and constitutional "borrowing"16 spurring debate in many polities. ${ }^{17}$ Some, such as Jackson, ${ }^{18}$ Tushnet, ${ }^{9}$ and Choudhry, ${ }^{20}$ have even posited specific tools, means, and modes for use by courts engaging with foreign constitutional and case law. This simultaneous rise in scholarship and legal integration in many realms (ranging from the geographically linked integration of Europe to the issue-linked integration of states in the World Trade Organization) has given a consequent rise to the urgency of discussions of legal independence and interdependence in countries outside the United States.

Though the academic, political, and judicial debates on foreign law have expanded in many dimensions, what remains lacking is any truly "comparative" understanding of how different countries approach this issue. That is, while the use or absence of foreign law in specific states is clear, there is little literature that attempts to use the experiences of given states in their use of comparative law as a tool to understand other states' decisions to do so. The primary concern of this essay is to start the process of filling this academic gap. This debate will be engaged by looking at the jurisprudence of the Supreme Court of India and by exploring how this body of law complicates discussions within the United States regarding the use of foreign law. Examples will be drawn from other countries to provide a more nuanced and complete exploration.

This comparative approach sheds light on the foreign law discussion in two key ways. First, it suggests that the debate, as it is framed both inside and outside the United States, reflects an oversimplification of the issues involved with the use (or neglect) of foreign law in domestic jurisprudence. The definition of "foreign law" and "usage," in addition to the specific placement and power of judicial structures within a political system, are powerful explicators, if not determinative factors, in a domestic court's decisions

15. See, e.g., Anne-Marie Slaughter, A Typology of Transjudicial Communication, 29 U. RiCH. L. ReV. 99 (1994); Anne-Marie Slaughter, Judicial Globalization, 40 VA. J. INT'L L. 1103 (2000).

16. See generally Mark Tushnet, Returning with Interest: Observations on Some Putative Benefits of Studying Comparative Constitutional Low, 1 U. PA. J. CONST. L. 325 (1998). But see Matthew Adler, Can Constitutional Borrowing be Justified? A Comment on Tushnet, 1 U. PA. J. CONST. L. 350 (1998).

17. For example, in Australia though "[the] use of international law to help resolve ambiguities in local legislation is by now well established, ... [it remains] . . controversial ... [to] use [international] ... source[s] to fill gaps in local legislation." The Hon. Justice Michael Kirby, The University Valedictory Address to Mark the Retirement of the Honourable Alastair Nicholson (Apr. 15, 2004), http://www.hcourt.gov.au/speeches/kirbyj/kirbyj_15apr04.html (last visited Apr. 28, 2005). Australian judges remain generally "sceptical [sic] or even hostile" to such broader usage of foreign law. $I d$.

18. See Vicki Jackson, Ambivalent Resistance and Comparative Constitutionalism: Opening Up the Conversation on "Proportionality," Rights and Federalism, 1 U. PA. J. CONST. L. 583 (1999).

19. See Mark Tushnet, The Possibilities of Comparative Constitutional Law, 108 YALE L.J. 1225 (1999).

20. See Sujit Choudhry, Globalization in Search of Justification: Toward a Theory of Comparative Constitutional Interpretation, 74 IND. L.J. 819 (1999). 
regarding foreign law usage. Second, by examining this issue through the Indian Supreme Court, it becomes evident that, given the unique structure and placement of the American Supreme Court--and indeed the entirety of the U.S. judicial system-American isolationist jurisprudence, though rare in world judicial thought, is arguably a reasonable reaction to the forces impacting the American judicial system. Still, the globalizing trends of private and public law suggest that those hoping to limit reliance on foreign law, both in the United States and elsewhere, are waging a losing battle.

II.

\section{THE AMERICAN DEBATE}

\section{A. Traditional Concerns and Responses}

Unpacking the concerns of those who argue against using foreign law is complicated by the breadth of views held by the camp: proponents of this position include a range from those preaching from a xenophobic position to the more reasoned logic of centrist practitioners. ${ }^{21}$ Though there are supporters of this isolationist view in other countries, one of this position's most erudite leaders is United States Supreme Court Justice Antonin Scalia. ${ }^{22}$ Taking his views as a broad representation of the school, it seems that anxieties regarding the use of foreign law rest on two fundamental complaints. First, proponents posit a functionalist argument, claiming that such use is inherently open to manipulation and misuse. Regarding the former, Scalia has claimed that use of foreign law by the bench rarely involves bona fide reliance on another country's jurisprudence. Rather, judges are wont to use such precedents in a selective manner, "cherry picking" opinions that support their viewpoint and ignoring contrary findings. ${ }^{23}$ This relates to the likely misuse of foreign precedent. In

21. See generally supra note 4 .

22. See generally Antonin Scalia, Commentary, 40 ST. LoUIS U. L.J. 1119 (1996). Other proponents of this position include Richard Posner, No Thanks, We Already Have Our Own Laws, LEGAL AFF. July/Aug. 2004, at 40 (arguing that "[ $\mathrm{t}]$ he court should never view a foreign legal decision as a precedent in any way"); Jonathan Hill, Comparative Law, Law Reform and Legal Theory, 9 OXFORD J. LEGAL STUD. 101, 101-15 (1989) (arguing that the method of comparative law is fraught with serious problems); and Robert Bork, Whose Constitution Is It, Anyway?, NAT'L REV., Dec. 8, 2003, at 37 (claiming that references to foreign jurisprudence are an "absurd tum in ... [American] jurisprudence," reflective of the arrogance of the modern judiciary). See also ROBERT BORK, COERCING VIRTUE: THE WORLDWIDE RULE OF JUDGES 22 (2003) (stating that there is an "insidious appeal" to referencing foreign law).

23. In his dissent in Lawrence $v$. Texas, a case in which the majority based its reasoning in part on the views of foreign nations/courts in invalidating laws criminalizing homosexual sodomy, Scalia notes that the "Court's discussion of these foreign views [ignores] . . the many countries that have retained criminal prohibitions on sodomy, [and] is therefore meaningless dicta." 539 U.S. 558 , 598 (2003). Posner argues that if "foreign decisions were freely citable, it would mean that any judge wanting a supporting citation had only to troll deeply enough in the world's corpus juris to find it." Posner, supra note 22, at 41-42. Supporters of the internationalization of U.S. Supreme Court jurisprudence note that some legal systems are much more apt to be cited than others. See, e.g., Anne-Marie Slaughter, Court to Court, 92 AM. J. INT'L L. 708, 710-11 (1998) (describing the interest of Justices $O^{\prime}$ Connor and Breyer in specifically applying European law). 
most parts of the world, judges seldom have a full understanding of the background jurisprudence of foreign decisions, ${ }^{24}$ which makes misapplication probable. As an example, Scalia posits that a citation supporting a "Miranda" rule in a foreign state may actually have little weight if that state does not provide enforcement through mandated exclusion of information garnered without its protections. ${ }^{25}$ While it may be clear that the "Miranda" rule exists, the existence of an exclusionary rule-a point of foreign law likely to be overlooked by the citing judge - is critical to a full understanding of the foreign law. 26

The second anxiety in this camp derives from the democratic rudiments of constitutional law. In the American case, this foundation, and a reflexive particularism/exceptionalism has historically served as the core of "most... theories of constitutional interpretation." 27 In the U.S., all power in the government is said to derive from the people, and judicial decisions are only given force because "the people" have, at least proximately, permitted their chosen judges to shape society's laws. ${ }^{28}$ This same permission has not been granted foreign judges, and the lack of democratic accountability which necessarily arises from the use of foreign judgments is consequently "unAmerican" and unconstitutional. Moreover, even without this democratic deficit, the uniqueness of the American constitutional experience would render any foreign understanding as normatively inappropriate for implementation. ${ }^{29}$ The force and appeal of these arguments, particularly the "exceptionalist" case, has made the "isolationist" school dominant in American jurisprudence and wider society, with critical legal debates both on the bench and in public conducted with "unapologetic insularity."30 "Isolationists" in other countries have long offered similar arguments, with some contending that certain aspects of foreign law have not developed with their state and are therefore irrelevant, ${ }^{31}$ while others resist the importation of law in order to stem changes in their "unique" legal institutions. ${ }^{32}$

24. Volkmar Gessner, Globalization and Legal Certainty, in EMERGING LEGAL CERTAINTY: EMPIRICAl Studies on tHE Globalization OF LAW 427 (Volkmar Gessner \& Ali Cern Budak eds., 1998).

25. Scalia/Breyer Debate, supra note 5; Miranda v. Arizona, 384 U.S. 436, 444-45 (1966) (mandating that arrestees be informed of their rights prior to custodial interrogation).

26. Gessner notes that "in general, lawyers [in most parts of the world] get little ... training in international or foreign aspects of law and are mostly unable to handle cross-border cases." Gessner, supra note 24 , at 437.

27. Choudhry, supra note 20 , at 838 .

28. Scalia/Breyer Debate, supra note 5 .

29. There are several versions of this debate, with central proponents including William $\mathbf{P}$. Alford, On the Limits of "Grand Theory" in Comparative Law, 61 WASH. L. REV. 945, 954 (1986) and Frederick Schauer, Free Speech and the Cultural Contingency of Constitutional Categories, 14 CARDOZO L. REV. 865 (1993).

30. MARY ANN GLENDON, RightS TALK: THE IMPOVERISHMENT OF POLITICAL DISCOURSE 14 (1991).

31. See Reiter, supra note 8 , at 467.

32. A primary concern of late has been the "decivilizing" of civil law through the introduction of common law precedent and procedure. Pierre Legrand, Civil Law Codification in 
The contrary, "internationalist" school also has several proponents in various countries, but in the interest of symmetry, this essay will take the group as represented by Scalia's colleague on the Supreme Court, Justice Stephen Breyer. ${ }^{33}$ Breyer posits not only that jurisprudence reliant solely on domestic precedents suffers from the same flaws isolationists claim are unique to usage of foreign law, ${ }^{34}$ but also that examining foreign law "may ... cast an empirical light on the consequences of different solutions to a common legal problem."35 For example, in Printz v. United States, Breyer dissented from the majority's ruling on a case involving federal powers and provided support for his reasoning with reference to practices in European federal systems. ${ }^{36}$ In "moral" cases, such as those related to the death penalty or the furtherance of personal freedoms, internationalist justices have regularly referred to an emerging "global consensus" to support their views. ${ }^{37}$ More broadly, internationalist jurists argue that as globalization increases, the problems faced by peoples throughout the world will become more similar, making reference to non-domestic law both valid and necessary. Because of this, Justice Sandra Day O'Connor has said that American judges will find themselves "looking more frequently to the decisions of other constitutional courts." 38 Finally, internationalists point to the

Quebec: A Case of Decivilianization, 1 ZEITSCHRIFT FÜR EUROPÄISCHES PRIVATRECHT 575 (1993); Grande, supra note 11.

33. Other judges, notably Justice Ruth Bader Ginsburg, are almost equally committed to the cause. In the affirmative action case, Grutter v. Bollinger, 539 U.S. 306 (2003), "Ginsburg noted with approval that the International Convention on the Elimination of All Forms of Racial Discrimination allows the theoretically temporary 'maintenance of unequal or separate rights for different racial groups' [and also] cited analogous provisions of the Convention on the Elimination of All Forms of Discrimination Against Women." Stuart Taylor, Let's Look to Zimbabwe: Should the Supreme Court Consider Foreign Precedent to Interpret our Constitution?, LEGAL TIMES, Mar. 8,2004 , at 46.

34. The same self-selectivity of case citations occurs in jurisprudence that relies only on domestic precedent and many judges who disdain the anti-democratic nature of foreign law citations nonetheless put value on "Brandeis" briefs and other sources that are created by similarly nondemocratic sources. For example, in Atkins v. Virginia, Justice Scalia saw no inconsistency in refusing to assess the mores of the world community but embracing the thoughts of Blackstone (both an ancient and unelected theorist) on what is meant by "cruel and unusual." 536 U.S. 304, 340 (2002) (Scalia, J., dissenting).

35. Printz v. United States, 521 U.S. 898, 977 (1997) (Breyer, J., dissenting).

36. Id. The two recent cases that have most antagonized isolationists are Lawrence, 539 U.S. 558, and Atkins, 536 U.S. 304. In Lawrence, Justice Kennedy's majority opinion rested in part on a 1967 vote in the British Parliament in favor of legalizing homosexual acts and a 1981 European Court of Human Rights ruling that those acts are enshrined as rights under the European Convention on Human Rights. 539 U.S. at 577. In explaining his ruling, Kennedy argued that "[the] right the petitioners seek in this case has been accepted as an integral part of human freedom in many other countries." Id. In Atkins, Justice Stevens used a European Union brief to buttress his case that the execution of mentally retarded murderers violates the Eighth Amendment of the U.S. Constitution. 536 U.S. at 316, n.21. He wrote that "within the world community, the imposition of the death penalty for crimes committed by mentally retarded offenders is overwhelmingly disapproved." $I d$.

37. As noted in Roper $v$. Simmons, "[over] the course of nearly half a century, the Court has consistently referred to foreign and international law as relevant to its assessment of evolving standards of decency." $125 \mathrm{~S}$. Ct. 1183,1215 (2005).

38. Anne-Marie Slaughter, The Real New World Order, 76 Foreign Aff. 183, 187 (1997) (quoting Justice Sandra Day O'Connor). See also Justice Sandra Day O'Connor, Keynote Address, 
imperative of candor: globalization means that even the most isolationist of judges will be increasingly influenced by foreign states; an acknowledgement that non-municipal systems play a role in judicial thinking is thus more honest than claiming otherwise. ${ }^{39}$

III.

\section{MisCONCEPTIONS OF THE DEBATE: AMERICA AND BEYOND}

While the tenor of the debate differs, both the American and non-American discussions share two fundamental shortcomings that have stunted both the effective use of, and understanding of, the internationalization of domestic law. The debates fail to define clearly the meaning of "foreign law," and they also inaccurately assume a level of judicial independence in determining whether foreign law ought to be used; such autonomy likely does not exist in the vast majority of the world's judiciaries. This section will discuss these misconceptions before focusing on the jurisprudence of the Indian Supreme Court-a jurisprudence that provides insights into how historical and political influences shape perceptions of foreign law and make it nearly impossible for judges to truly independently decide whether to use foreign law.

\section{A. Definitional Obfuscation}

Arguments concerning foreign law remain clouded by equivocal terminology. It is unclear just what is meant by "foreign" precedent. In multinational states, with histories of colonialism, occupation and/or influence by others, and increasing legal inter-connectedness with other countries, the line between "foreign" and "domestic" for concepts as intangible as "legal principles" has always been imprecise and is becoming more so. The Napoleonic civil codes adopted throughout Europe and many of its possessions in the nineteenth century illustrate the difficulty of determining where domestic law ends and foreign law begins. In each case of implementation, whether in Italy, the Netherlands or Louisiana, the code was adapted in varying ways to meet local conditions. Its core, "foreign" elements persisted, but its peripheries were often radically altered. Was the code nonetheless foreign? Moreover, does "foreign" truly imply "extra-territorial" provenance or just extra-parliamentary? Are references to tribal or indigenous law, rather than legislatively enacted codes, reliance on "foreign law"?

The word "law" itself has also never fully been described in reference to

96 AM. SOC'Y INT'L L. Proc. 348, 350 (2002).

39. Tim Wu, Foreign Exchange: Should the Supreme Court Care What Other Countries Think?, SLATE, Apr. 9, 2004, http://slate.msn.com/id/2098559/.

40. Native land title issues, which have received growing prominence in many parts of the world, have brought the justiciability, let alone validity, of the sources of such native law to the fore. See, e.g., Richtersveld Community v. Alexcor, 2003 (6) SA 104 (SCA) (S. Afr.); Mabo v. Queensland II (1992) 175 C.L.R. 1 (Austl.); Ngati Apa v. Attorney-General [2003] 3 N.Z.L.R. 643 (C.A.). 
the use of "foreign law." Traditionally, comparative law has focused only on legal texts in foreign states; however, insights into how a law in a foreign country has actually worked-which seems a crucial element in effective usage - can be found in studies of comparative constitutional sociology, and in disciplines far removed from the law. ${ }^{41}$ Would reference to such scholarship be citing to foreign law?

Additionally, it is unclear whether laws (foreign or domestic) need to be concrete for their use to be imputed. That is, does reference to uncodified norms of international behavior, so-called "customary international law," or the use of "informal norms and institutions" 42 - both of which may play determinative legal roles-constitute judicial use? Similarly, few scholars have analyzed just what "use" of foreign law implies. It seems clear that inclusion of foreign law as binding or persuasive precedent would likely fit into most constructions, but is it a true "use" of foreign law if a court adopts foreign theoretical concepts rather than "law," 43 or if the sole use of a foreign citation is to borrow its canon of construction rather than its holding? ${ }^{44}$

Institutional "borrowing" adds a further dimension to the definitional quandary. Newer constitutional and quasi-constitutional states, ${ }^{45}$ such as the Philippines, New Zealand, South Africa, and states in Central and Eastern Europe, have explicitly borrowed ${ }^{46}$ from other countries, often transplanting institutions and ideas into their founding documents. ${ }^{47}$ The impact of this

41. See, e.g., David Fontana, Refined Comparativism in Constitutional Law, 49 UCLA L. REV. 539 (2001) (promoting such an approach); ALAN WATSON, LEGAL TRANSPLANTS: AN APPROACH TO COMPARATIVE LAW 9 (1974); Gunter Frankenberg, Critical Comparisons: ReThinking Comparative Law, 26 HARV. INT'L L.J. 411 (1985); Rodolfo Sacco, Legal Formants: A Dynamic Approach to Comparative Law, 39 AM. J. COMP. L. 1 (1991); RICHARD POSNER, LAw AND LEGAL THEORY IN ENGLAND AND AMERICA 70 (1996).

42. Daniel Berkowitz, Katharina Pistor \& Jean-Francois Richard, The Transplant Effect, 51 AM. J. COMP. L. 163, 170 (2003).

43. Wiegand, supra note 9 , at 245.

44. For examples of such "use," see South Africa's National Coalition for Gay and Lesbian Equality v. Minister of Home Affairs, 2000 (1) BCLR 39 (CC) at I 25 (S. Afr.) (referring to decisions from the House of Lords and the New Zealand Court of Appeal in determining the meaning of "spouse"), and India's Gramophone Co. v. Birendra Bahadur Pandey, A.I.R. 1984 S.C. 667 (using various international conventions and treaties (some to which India was not party) in interpreting whether India's trademark laws were applicable to goods in transit over India).

45. This borrowing has also occurred for "pure" common law states - absent a written bill of rights-such as Israel and Australia. Here, instead of structural and functional components of constitutions, they have borrowed jurisprudence. See Pnina Lahav, American Influence on Israel's Jurisprudence of Free Speech, 9 HASTINGS CONST. L.Q. 21 (1981); Gerald N. Rosenberg \& John M. Williams, Do Not Go Gently Into That Good Right: The First Amendment in the High Court of Australia, 1997 SUP. CT. REV. 439 (1997).

46. This borrowing has occurred both at the textual level-importing various items into new constitutions-as well as the interpretative level. For example, in the Lithuanian case "[o]n the death penalty provided for by sanction of Article 105 of the Criminal Code" (1998), the Constitutional Court held that "the State of Lithuania, of its own free will, adopts and recognizes ... the customs of the international community, and naturally integrates itself into the world culture," http://www.lrkt.lt/dokumentai/1998/n8a1209a.htm (last visited Apr. 25, 2005).

47. See Roman Herzog, Foreword to the First Edition, in ThE Constitutional JURISPRUDENCE OF THE FEDERAL REPUBlIC OF GERMANY xi-xii (Donald P. Kommers ed., 2d ed. 
borrowing on the line between foreign and domestic law is significant. For example, though the New Zealand Bill of Rights is incorporated into its domestic law, that it was explicitly drawn from United States and Canadian constitutional experiences ${ }^{48}$ suggests that the word "foreign" would be distorted if it were not used to describe the New Zealand courts' reliance on their own Bill of Rights. ${ }^{49}$ The healthy "overseas trade" in the American Bill of Rights ${ }^{50}$ and often accompanying case law-and the more recent trade in the Canadian Charter of Rights and Freedoms ${ }^{51}$ - has meant that for many countries' judiciaries, an assessment of basic rights and foundational principles inherently implies reference to foreign jurisdictions. ${ }^{52}$ Some judges have argued that the practice ought to work both ways and since the constitutional systems of so many countries are the direct "offspring" of the American model, the experiences of such nations are manifestly relevant in interpreting the American Constitution. ${ }^{53}$ It is equally unclear whether such reliance of the constitutional "parents" on their offspring's experiences would entail truly "foreign" citation.

The conflation of the foreign and domestic for older constitutional states like the United States is not solely a function of modern re-borrowing of constitutional doctrine from states that have adopted their models. Rather, the history of the American, and other comparatively ancient constitutional systems, are also not immune from this importing phenomenon. ${ }^{54}$ Such states are

1997); Jeremy Sarkin, The Effect of Constitutional Borrowings on The Drafting of South Africa's Interim Bill of Rights and the Role Played by Comparative and International Law in the Interpretation of Human Rights Provisions By the Constitutional Court, 1 U. PA. J. CoNST. L. 176 (1998); Imre Voros, Contextuality and Universality: Constitutional Borrowings on the Global Scale-The Hungarian View, 1 U. PA. J. CONST. L. 651 (1998); Wojciech Sadurski, Postcommunist Charters of Rights in Europe and the U.S. Bill of Rights, 65 LAW \& CONTEMP. PROBS. 223 (2002); Andzrej Rapaczynski, Bibliographical Essay: The Influence of U.S. Constitutionalism Abroad, in CONSTITUTIONALISM AND RIGHTS: THE INFLUENCE OF THE UNITED STATES CONSTITUTION ABROAD 405, 435-36 (Louis Henkin \& Albert J. Rosenthal eds., 1990); Crawford Young, The Debate on Democratization in Africa, in THE U.S. CONSTITUTION AND CONSTITUTIONALISM IN AFrICA 121, 122 (Kenneth W. Thompson ed., 1990); Watson, supra note 41; Klug, supra note 13.

48. See NEW ZEALAND MINISTRY OF JUSTICE, THE GUIDELINES ON THE NEW ZEALAND BILL OF RIGHTS ACT 1990, http://www.justice.govt.nz/pubs/reports/2004/bill-of-rightsguidelines/index.html (last visited Apr. 20, 2005).

49. In addition to the U.S., New Zealand has engaged in other trans-jurisdictional borrowing, drawing on, inter alia, Scandinavian, Canadian, Australian, and German sources. See K.J. Keith, The New Zealand Bill of Rights Experience: Lessons for Australia, http://www.gtcentre.unsw.edu.au/publications/papers/docs/2002/89_KennethKeith.pdf, presented at The Gilbert \& Tobin Centre of Public Law 2002 Bill of Rights Conference.

50. Lester, supra note 12.

51. See Edward McWhinney, The Canadian Charter of Rights and Freedoms: The Lessons of Comparative Jurisprudence, 61 CAN. B. REV. 55 (1983); Choudhry, supra note 20, at 821.

52. See generally Louis Henkin, A New Birth of Constitutionalism: Genetic Influences and Genetic Defects, 14 CARDozo L. REv. 533, 533 (1993).

53. See United States v. Then, 56 F.3d 464, $468-69$ (2d Cir. 1995) (Calabresi, J., concurring). See also Carol Steiker, Pretoria, Not Peoria, 74 TEX. L. REv. 1285 (1996).

54. For a comprehensive overview of the history of foreign law citation in the U.S. Supreme Court context, see Steven Calabresi \& Stephanie Zimdahl, The Supreme Court and Foreign Sources of Law: Two Hundred Years of Practice and the Juvenile Death Penalty Decision (Apr. 2005), http://ssrn.com/abstract=700176. 
similarly derived from other polities and the heavy reliance on English law and pan-European enlightenment ideals ${ }^{55}$ in the drafting of America's founding documents ${ }^{56}$ produces a similar result when its courts are called on to interpret them. Sometimes this has been explicit, as in the U.S. Court's 1877 opinion Pennoyer v. Neff, ${ }^{57}$ while at other times the Court has been known to find support for positions by reference to "rights older" than the Constitution, ${ }^{58}$ and thus implicitly implicate rights outside the confines of the 1789 compact.

Even English courts, which have enjoyed an essentially uninterrupted run of 800 years and which cannot fall back on a codified constitution, have resorted to foreign law, with commentators noting that the English system has always been a "foreign blend." parliamentary "foreign" body of law: in cases dealing with foundational principles and rights, courts have historically relied on religious edicts, a body of law that, if not foreign, is at least "extra-parliamentary."60 More recently, English law has become enmeshed with that of Europe and other non-domestic case law has similarly crept into the canon. ${ }^{61}$ In short, it seems that in almost all states, it is not whether foreign principles are relied upon, but whether courts and societies recognize them for what they are.

\section{B. Assumption of Judicial Independence}

A second similarity between the American and non-American discussion is perhaps even more fundamental to the debate: a base premise of the discussion, in almost any of its guises, is that judges play an autonomous role in the process

55. Richards notes that there was significant international pollination of the American Constitution, with framers referring to such nationally diverse scholars as Machiavelli, Harrington, Montesquieu, Smith, Ferguson, and Millar. David Richards, Revolution and Constitutionalism in America, 14 CARDOZO L. REV. 577, 584-86 (1993).

56. Even Justice Scalia acknowledges the relevance of comparison with foreign jurisdictions during the process of writing constitutions, if not in their subsequent interpretation. Breyer/Scalia Debate, supra note 5. See also Lester, supra note 12, at 537.

57. 95 U.S. 714 (1877). In Pennoyer, the Court held that states were judicially powerless outside their borders, a holding rationalized through reference to public international law. This decision remains in force today, and serves as a foundation of domestic jurisdiction in the United States.

58. In Griswold v. Connecticut, the majority held that the "right of privacy [is] older than the Bill of Rights-older than our political parties, older than our school system." 381 U.S. 479, 486 (1965).

59. Peter Stein, Legal Science during the Last Century: England, in LA SCIENCE DE DROIT AU COURS DU DERNIER SIĖCLE 40 (Melanges Rotondi ed., 1976).

60. Historically, the English common law incorporated ecclesiastical law as well as other aspects of ancient English law. See LeBarron v. LeBarron, 35 Vt. 365, 367 (1862). An earlier case provided explicit reference to religion, holding that "Christianity is part of the law[.]" Rex v. Curl, (1727) 2 Eng. Rep. 849,850 (K.B.).

61. Most broadly, the Human Rights Act of 1998 incorporates the European Convention of Human Rights (and binding interpretations of the compact emanating from the European Court of Human Rights) into English law, requiring all domestic law to be read and given effect in a way compatible with the Convention. Human Rights Act, 1998, c. 42 (Eng.), in 7 HaLSBURY's StatuTES OF ENGLAND AND Wales 528 (2002). See also Jane Wright, Tort Law and Human Rights - The Impact of the ECHR on English Law, 13 KINGS C.L.J. 253 (2002). 
of using foreign law. Examinations of the "motives" driving national courts to engage in particular actions, ${ }^{62}$ suggestions that courts select from among a set of "modes of interpretation"63 when borrowing constitutional doctrines, or arguments that judges can choose whether to "receive" foreign law or engage in a "dialogue" with foreign jurisdictions, ${ }^{64}$ assume significant freedom on the part of jurists. Such theories imply that judges have the flexibility to act to incorporate or disregard foreign precedents. However, as this essay will attempt to demonstrate, this is not necessarily an accurate description of the judicial position in almost any domestic system and thus might not correctly describe how foreign law is incorporated or ignored in domestic judicial jurisprudence. Complete judicial independence-even in the most consolidated and longstanding of democracies-is illusory; judges remain a part of the social and political fabrics of their societies, a position that both empowers them and critically constrains the choices they make on the bench. ${ }^{65}$ The use or neglect of foreign law is one aspect of these limitations.

Dependent upon institutional strength, esteem, and wider social goals, courts may be severely constrained in all aspects of their decision making, including their use of foreign law. For example, judges in a newly independent state may be reticent to refer to the law of the former colonial power for fear that doing so would stunt the nation-building process and brand their branch as ante bellum. In such situations, reference to laws of different jurisdictions (the former metropole compared with others, for example) would have different impacts and meanings. More prosaically, courts may be bound by explicit political decisions which likewise put pressure on their resort to foreign precedent. States' members of the Council of Europe, legally bound by the decisions of the European Court of Human Rights, compel their domestic judiciaries to take into account precedents emanating from the Strasbourg court. ${ }^{66}$ The prerogative of judges in these forty-six countries not to use foreign law is progressively more limited due to decisions by their governments to more closely integrate their law with neighboring states.

This complex interplay between court and society suggests a further dimension over which foreign law is played out in domestic jurisprudence that has been similarly lacking from the debate. Judges and societies are dynamic entities, with their powers and competencies in constant flux. The resort to foreign law, inter alia, is a result of the perpetual dialectic between the two, with

62. Slaughter, supra note 15.

63. Choudhry, supra note 20 (contending that there are distinct normative justifications for the use of comparative law); Tushnet, supra note 19 (arguing that there are three modes by which a state can learn from fellow constitutional nations--functionalism, expressivism, and bricolage).

64. Claire L'Heureux-Dube, The Importance of Dialogue: Globalization and the International Impact of the Rehnquist Court, 34 TULSA L.J. 15 (1998).

65. See, e.g., Gerald Rosenberg, Judicial Independence and the Reality of Political Power, 54 Rev. POL. 369, 394-95 (1992); J. Mark Ramseyer, The Puzzling (In)dependence of Courts: $A$ Comparative Approach, 23 J. LEGAL STUD. 721 (1994).

66. See F.G. Jacobs, Public Law-The Impact of Europe, PUB. L. 232 (1999); Ray Murphy, The Incorporation of the ECHR into Irish Domestic Law, 6 EUR. HUM. RTS. L. REv. 640 (2001). 
the use or absence of foreign law in specific cases helping to elucidate the current relationship between courts and other social bodies. For instance, in a post-colonial state, a period during which the courts manifest a desire to reduce reliance on the colonial power's laws will sometimes be followed by a rerecognition of the value of the colonial system's precedents. This processwhich occurred in India-may indicate the end of the post-colonial, independence phase of nation building, and the beginnings of a more nuanced relationship between former colonialists and colonizers.

Seen in this light, the American debate regarding the use of foreign sources is less remarkable, and "the rejection of foreign law by the U.S. Supreme Court... can be seen as a response to both local and global influences." $" 67$ Since Marbury v. Madison, ${ }^{68}$ the U.S. courts have built a strong place within the political structure, confident that their rulings will be obeyed. In general, the Court's confidence has proven warranted. ${ }^{69}$ In support of the "isolationist" school, there is arguably enough history and esteem for today's U.S. courts to rely solely on their own precedents. Though the "domestic" principles on which isolationists would like the courts to rely are likely proximately related to nonmunicipal law, the connection is sufficiently attenuated to satisfy supporters of the doctrine. Further, the executive and legislative branches, by limiting extraterritorial legal entanglements, ${ }^{70}$ have rarely, if ever, required the judiciary to consider foreign law. In addition, the United States is large and heterogeneous enough to keep producing novel, complex legal problems on which domestic courts will be able to draw. ${ }^{71}$

Yet, despite the unique strengths of the American judiciary and the ability of the courts, especially with regards to analyses of fundamental rights, to be insulated "from the vicissitudes of political controversy," 72 even the independence of American jurists is in some doubt. Mishler and Sheehan have argued that U.S. Supreme Court justices (who are lifetime appointees) remain

67. Sarah K. Harding, Comparative Reasoning and Judicial Review, 28 YALE J. INT'L L. $409,412(2003)$.

68. 5 U.S. 137 (1803).

69. There are few cases in which the Court's explicit orders have been flouted; the most famous was Lincoln's failure to uphold habeas corpus during the Civil War, despite a direct court order (Ex parte Merryman, 17 F. Cas. 144 (1861)). See generally WILliam REHNQUIST, ALL THE LAWS BUT ONE (1998).

70. It is only in the realm of trade that the U.S. has become internationally legally entangled. The U.S. has opted out of the International Criminal Court and has not only regularly failed to implement decisions rendered by the International Court of Justice, but has also refused to recognize the Court's jurisdiction. See Adam Liptak, U.S. Says it Has Withdrawn from World Judicial Body, N.Y. TIMES, March 10, 2005, at A16.

71. Some suggest almost all new legal problems are recognized and discussed first in the United States. Wiegand, supra note 9, at 245. Consequently, the world's reliance on American ingenuity leads to another argument against using foreign law in American jurisprudence. Such use is counterintuitive; the United States is a net provider of law to other states, with states turning to it for guidance. The global consensus, in this regard, is that the United States model is the correct one; why should American judges-especially those concerned about the "global consensus"-look elsewhere?

72. W. Virginia State Bd. of Educ. v. Barnette, 319 U.S. 624, 638 (1943). 
nonetheless "broadly aware of fundamental trends in ideological tenor of public opinion, and that at least some justices... adjust their decisions... to accommodate such fundamental trends." 73 Given the importance of the issue of foreign law usage - manifested, in part, by the fervency of the debate-it seems reasonable to suggest that the use or nonuse of such precedents may be among the "fundamental trends" to which Justices respond.

Moreover, even if the U.S. courts were as independent as some claim, it is clear that the majority of world judiciaries have neither the histories nor institutional capacities to solely focus on domestic principles. ${ }^{74}$ Rather, in a complex interaction with their societies, courts determine how to make decisions so as to enhance their institutional strength, with constitutional interpretationlet alone the use of foreign law-just one of the "multiple poles in a complex field of forces, among which judges navigate and negotiate." 75 This article will attempt to demonstrate this complexity through a detailed examination of the jurisprudence of the Indian Supreme Court from its founding in 1950 through 2004. The relatively short history of the Court, combined with the tumult of Indian politics and the varying extensiveness of connections between India and the outside world during that time, makes the Court a powerful tool for analyzing the complexities and complementarities of domestic use of foreign law. The constraints on Indian judges and the ambiguity between foreign and local laws are evident.

Though the use of foreign law may not be as incendiary in the Indian context as it has been in many other systems, the Indian independence movement, combined with arguments made by Indian politicians and judges regarding the encroachment of foreign law on domestic prerogatives, ${ }^{76}$ suggests that foreign law is nonetheless still controversial in the construction of India's domestic jurisprudence. To varying degrees, the history of Indian law and the state of Indian society are reflected in the use and reliance on foreign law by

73. William Mishler \& Reginald Sheehan, The Supreme Court as a Counter Majoritarian Institution? The Impact of Public Opinion on Supreme Court Decisions, 87 AM. POL. SCI. REV. 87, 89 (1993); Helmut Norpoth \& Jeffrey Segal, Popular Influence on Supreme Court Decisions: Comment, 88 AM. POL. SCI. REv. 711 (1994); William Mishler \& Reginald Sheehan, Popular Influence on Supreme Court Decisions: Response, 88 AM. POL. SCI. REV. 716 (1994); Roy Flemming \& Dan Wood, The Public and the Supreme Court: Individual Justice Responsiveness to American Policy Moods, 41 AM. POL. SCI. REV. 468 (1997). For a more recent comment on the topic, see Lee Epstein et al., The Effect of War on the U.S. Supreme Court (Sept. 1, 2004), http://lawweb.usc.edu/faculty/workshops/documents/Epstein.pdf (demonstrating that during times of war, national security concerns directly impact decisions of the Supreme Court in cases unrelated to issues of national security).

74. In addition to institutional strictures, some scholars have noticed a growing trend towards the establishment of explicit monitoring of judicial responsibility. See generally Mauro Cappelletti, Who Watches the Watchmen? A Comparative Study on Judicial Responsibility, 31 AM. J. COMP. L. 1 (1983).

75. Frank Michelman, A Constitutional Conversation with Professor Frank Michelman, 11 S. AFR. J. HUM. RTS.477, 483 (1995).

76. For example, in M.C. Mehta v. Union of India, Justice Bhagwati argued: "The Court cannot allow judicial thinking to be constricted by reference to the law as it prevails in England or in any other foreign country." (1987) S.C.R. (1) $819,823$. 
Indian courts to justify their own decisions.

IV.

\section{THE INDIAN EXAMPLE: DEFINITIONS AND HISTORICAL INFLUENCES}

This section provides a brief historical background of the Indian case. Such a foundation is critical given the hypothesis that the external environment in which courts operate is a critical component in analyzing their resort to foreign law. As will be demonstrated below, the pre-Independence and preconstitutional history of India clouds the definition of "foreign" in its legal system, while the country's history since independence and constitutional ratification greatly impacts any understanding of how free its courts have been to use foreign law in their decisions.

\section{A. Foreign Roots of Domestic Law}

The extreme and often volatile diversity within the Indian state accounts for the difficulty the country has had in forging a coherent definition of the "Indian" values and mores that would be reflected in its law. As a result, this same seemingly untenable diversity is present in India's legal structure, with its legal history revealing the system to be as much an amalgamation of traditions as is the wider Indian culture.

Tracing modern India's legal history to the country's independence in 1947 , or even to the ratification of its constitution three years later, neglects the fact that much of the complexity in India's domestic jurisprudence stems from the influences of the cultures, peoples, and laws that interacted with the subcontinent prior to Independence. Ranging from the Mughals, whose Muslim code remains a part of the fabric of modern Indian law, ${ }^{77}$ to the French, whose impact extended far beyond their officially minimal possessions, ${ }^{78}$ the multifarious past makes modern, domestic Indian law a construction of domestic and non-domestic processes and precedents. Key in this regard was the colonial era resort to Privy Council decisions, with the pre-1947 judiciary both bringing Indian cases to the body and referring to decisions of the body as persuasive and binding precedent. The corpus of transnational common law created through this process was explicitly kept alive through the Indian Constitution's Article 372 , holding that all laws in place prior to the constitution's passage were to remain in place unless repealed. ${ }^{79}$ Though British laws were the bulk of these pre-Independence codes-unsurprising since Britain was the most powerful

77. Symposium: The Relevance of Religion to a Lawyer's Work, 66 FORDHAM L. REV. 1593, 1593 (1998); Robert Baird, Traditional Values, Governmental Values, and Religious Conflict in Contemporary India, 1998 BYU L. REV. 337, 344-45 (1998). See generally PARAS DIWAN, MUSLIM LAW IN MODERN INDIA (1987).

78. See generally DAVID ANNOUSSAMY, THE FRENCH LEGAL SYSTEM AND ITS INDIAN CONNECTIONS (1995). The French relinquished their holdings in India-consisting of the easterm region of Pondicherry-in 1956.

79. INDIA CONST. art. 372. 
influence in India from 1600 until $1947^{80}$-Mughal, French, Portuguese, ${ }^{81}$ religious, and other ${ }^{82}$ laws also played a role.

Modern India has also been strongly influenced by many states that never ruled its territory. For instance, American influence can be found both in the state's judicial process and its constitutional text. ${ }^{83}$ The Indian Constitution's express declaration of fundamental rights coupled with the introduction of judicial review ${ }^{84}$ marked a radical departure from the British doctrine of parliamentary supremacy, and thoroughly "Americanized" the system. ${ }^{85}$ In addition to judicial review, the framers of the Indian Constitution explicitly used the American Bill of Rights as a starting point in their discussions. ${ }^{86}$ Moreover, India even adapted its constitution upon the recommendation of an American jurist. Following the terror of partition and Mahatma Gandhi's assassination, many representatives to the constitutional convention began to argue for carving out a constitutional allowance for preventive detention, placing "citizens' freedom at the disposition of a legislature for the sake of a public peace." ${ }^{\prime 87}$ As a result, constitutional guarantees to due process were removed from the document, a change supported by (and potentially instigated by) U.S. Supreme Court Justice Felix Frankfurter, who served as an unofficial-though evidently persuasive-legal consultant to the assembly. ${ }^{88}$

This absence of due process led to further components of explicit

80. See generally MoOLAMATtOM PYLEE, CONSTITUTIONAL GOVERNMENT IN INDIA 47139 (1977) (discussing the establishment of the East India Company, its subsequent control over India, the commencement of India's struggle for freedom, and the developments leading to India's independence from Great Britain). England assumed full control over India by the second half of the eighteenth century; in the aftermath of World War II, independence for India became imminent. Id. at $120-39$.

81. The Portuguese had a continuous presence in India for more than 450 years and only ceded its possessions-Goa, Daman and Diu, Dadra and Nagar Haveli-in 1961, more than a decade after Indian independence. See generally Michael N. PEARson, THE PORTUGuese IN INDIA (1988).

82. The Danes and the Dutch also had an early, ephemeral presence in India. JOHN KEAY, INDIA: A HISTORY 323, 348 (2001); Peter Ravn Rasmussen, Tranquebar, the Danish East India Company 1616-1669 (September 23, 1996), http://www.scholiast.org/history/tra-narr.html. See generally OM PRAKASH, THE DUTCH EAST INDIA COMPANY AND THE ECONOMY OF BENGAL, 1630-1720 (1985); KAy LARSEN, De DANKS-OSTINDISKE KolONIERS HISTORIE; TRANKEBAR (1907).

83. See Granville austin, The indian Constitution: Cornerstone of a Nation (1966); Pratap GHOSH, THE CONSTITUTION OF INDIA: HOW it HAS BEEN Framed (1966).

84. INDIA CONST. art 13, cl. 1.

85. The Indian constitutional assembly was so influenced by the American model-in contraposition with the English system which seemed a more historically appropriate fit-that it was felt that the Potomac, not the Thames flowed through the process. See Shamsher Singh v. State of Punjab, A.I.R. 1974 S.C. $2192,2212$.

86. See generally M. Abel, American Influences on the Making of the Indian Constitution, 1 J. CONST. PARLIAMENTARY STUD. 35 (1967); Soli Sorabjee, Equality in the United States and India, in CONSTITUTIONALISM AND Rights: ThE INFLUENCE OF THE UNITED STATES CONSTITUTION ABROAD 94 (Louis Henkin \& Albert J. Rosenthal eds., 1990).

87. Vijayashri Sripati, Human Rights in India-Fifty Years after Independence, 26 DENV. J. INT'L L. \& POL'Y 93, 100 (1997) (quoting Austin, supra note 83, at 102).

88. Sorabjee, supra note 86 , at $96-97$. 
international borrowing in the construction of the Indian compact, ${ }^{89}$ most notably from the Irish and Japanese Constitutions. India's removal of due process was not predicated on an aversion to fair procedure, but rather on the concern for the unmanageability of the expanses of "substantive" rights that had been wedged into the procedural right in the American context. Thus, the convention sought a more delimited way to protect the application of the rule of law. In the end, the convention opted to borrow from the Japanese Constitution, codifying the protection of citizens from governmental acts that violated "procedures established by law," 90 rather than the more amorphous "due process."

The Indian Constitution's commitment to establishing a government "guided" by fundamental rights also led to its borrowing from the Irish Constitution. The Indian version adopted Ireland's provision of "directive principles" by which state policy ought to be guided. Both the Irish and Indian Constitutions contain a list of non-justiciable social rights. The article containing these rights in the Irish Constitution-the force of which India adopts in Part IV of its constitution-states that "[the] principles of social policy set forth in this Article are intended for the general guidance of the [Parliament]. The application of those principles ... shall not be cognisable [sic] by any Court under any of the provisions of this Constitution." 91

Despite the non-justiciability ${ }^{92}$ of the directive principles, the Indian Constitution places a heavy emphasis on individual liberties. The document includes enforceable protections ${ }^{93}$ against infringement of speech and freedom of religion and, in the document's Article 21, a potentially expansive protection of "life and personal liberty." 94 The impact of these rights, however, would prove limited, especially in the early history of Indian Independence. The

89. The Indian Constitution borrowed clauses from many sources. For example, Article 51 corresponds to Article 29 of the lrish Constitution, Articles 28, 29, and 30 of the Soviet Constitution, and Article 6, section 2 of the American Constitution. Apart from direct parallels, the document also has close similarities with various international charters and covenants, borrowing from Articles 28 and 29 of the UDHR, Articles 1 and 2 of the International Covenant on Economic, Social and Cultural Rights, and Articles 1, 4 and 22 of the International Covenant on Civil and Political Rights. C. H. Alexander, The International Law in India, 1 INT'L \& COMP. L.Q. 289 (1952).

90. JAPAN CONST. art. 31.

91. IR. CONST., 1937, art. 45, available at http://www.taoiseach.gov.ie/upload/static/256.pdf (last visited Nov. 8, 2005).

92. Exactly how non-justiciable these principles are remains to be seen. In other states where such principles have been implicitly or explicitly appended to the constitution, they have attained the status of being "at least partially justiciable," despite constitutional pronouncements to the contrary. For the South Africa case, see Cass Sunstein, Social and Economic Rights? Lessons from South Africa, 11 CONST. FORUM 123, 125 (2000) and Ex parte Chairperson of the Constitutional Assembly: In Re Certification of the Constitution of the Republic of South Africa 1996 (10) BCLR 1253 (CC) (S. Afr.) (holding that socio-economic rights "are, at least to some extent, justiciable"). For the Irish case, see Ryan v. Attorney General [1965] I.R. 294 (Ir.) (holding that certain justiciable, unenumerated rights could be derived from the directive principles).

93. INDIA CONST. art. 32.

94. Article 21 states: "No person shall be deprived of his life or personal liberty except according to procedure established by law." INDIA CONST. art. 21. 
emergence of independent India saw the simultaneous birth of political hegemony under the Congress Party, promulgating socialist, collectivist measures in the economy and society. ${ }^{95}$ Many of these measures contested the fundamental, personal rights ensconced in the Constitution. Despite its mandate to protect such rights, so strong was Congress-backed parliamentary sovereignty, the Supreme Court would become passively and, at times, actively complicit in rendering many fundamental rights illusory.

\section{B. India's History Since Independence and Constitutional Ratification}

\section{i. Rise of Congress Party Hegemony}

Originally formed in 1885 - and coming to a head with the passage of the India Act in 1937 and eventual independence a decade later - the Congress Party emerged as the leading force in Indian political and social life. As the "independence" party, it assumed the task of simultaneously militating for the British departure and constructing an Indian identity. First under Mahatma Gandhi and later with greater zeal under Jawaharlal Nehru, Congress gained unquestioned dominance over almost all aspects of the Indian state and held onto its power for nearly three decades following independence. United in the post-independence, anti-colonial freneticism that marked many post-World War II independence movements, Congress successfully established its hegemony by invoking the socialist, communitarian notions that provided its philosophical and emotional support. Patronage and clientalism were important parts of the leadership model, ${ }^{96}$ with party supporters appointed to posts throughout the national and state-level bureaucracies, including judgeships. This, in turn, increased the party's control, with party appointees (or supporters) controlling not just the center but also state and local governments. Though there were tensions during the first years after independence-resulting from the partition with Pakistan and the attempt to incorporate vastly divergent local groups into a collective identity - the party managed to maintain and strengthen its national grip. $^{97}$

\section{ii. Fall of Congress and Atomization of the State}

Given his identification with the party, Nehru's death in 1964 was tumultuous for Congress. Though Nehru's daughter, Indira Gandhi, emerged as the party's new leader, without the prestige of her father's legacy she was unable

95. At the time, it was argued that the "Congress government, in its enthusiasm for economic development ... lost sight of the fundamental nature of the constitutional law." A. Gledhill, Constitutional and Legislative Development in the Indian Republic, 20 BULL. OF THE SCH. OF ORIENTAL AND AFR. STUD. 271 (1957).

96. Marcus Franda, The Organizational Development of India's Congress Party, 35 PAC. AFF. 248 (1962).

97. See generally James Manor, Parties and the Party System, in INDIA's DEMOCRACY: AN ANALYSIS OF CHANGING STATE-SOCIETY RELATIONS 62 (Atul Kohli ed., 1988). 
to provide a unifying force. The party's nationalist image began to break down, becoming viewed solely as a vehicle for elites and, following several cases of corruption, a hackneyed, self-serving organization. ${ }^{98}$ Congress was so enmeshed with the state and the electorate that its slow breakdown led to the increasing fragmentation of the Indian polity as a whole.

The 1967 elections were a watershed in Indian politics. Though the party managed to maintain its national leadership, the swing against Congress at the state level was pronounced, resulting in non-Congress regimes gaining power in some of the most important regions. Congress itself became divided through defeat, creating tensions which finally exploded in 1969, when Mrs. Gandhi was expelled from the Congress and formed her own party. The Congress Party's internal fractures were emblematic of a larger emerging "crisis of governability," demonstrated by the absence of enduring coalitions, a growing political ineffectiveness in dealing with important problems, and an inability to accommodate growing political conflict (including regional demands) without resorting to force and violence. ${ }^{99}$ By the early 1970 s, though Congress retained political control at the center, major changes were under way, signaled by the decline of almost all national institutions, especially the Congress Party.

In June 1975, as a result of declining control of the party machine and rising violence, Prime Minister Gandhi promulgated a state of emergency, during which she suspended democracy and many crucial personal rights. The Prime Minister ordered censorship of the press, canceled elections, detained thousands of opposition party members, and outlawed groups deemed antithetical to national values. ${ }^{100}$ The impact of and reaction to the Emergency led to the Congress Party suffering its first national electoral defeat in 1977. Since then, though Congress has recaptured power intermittently, the hegemony of the Congress Party has weakened still further. While it remains a primary actor in Indian politics, non-Congress prime ministers have governed the country seven times since the lifting of the Emergency.

State fracture continued into the 1980 s, with the breakdown not just of the Congress Party but of the Nehru-Gandhi dynasty that had led it. As a result of growing blocs of power emanating from regional, caste, and other narrow interests, national politics in India became marked by the rise of weak coalition governments and the formation of hundreds of new parties, the majority focused on specific class-, caste-, or region-based interests. ${ }^{101}$ By the end of the 1980s, almost all central, national institutions were emasculated, a trend furthered via weak, minority governments and the demise of the Soviet Union-a significant backer of India's planned economy.

98. Hilton Root, India: Asia's Next Tiger?, Hoover Institution Essays in Public Policy, http://www-hoover.stanford.edu/publications/epp/82/a.html (last visited Apr. 18, 2005).

99. See generally ATUL KOHLI, DEMOCRACY AND DISCONTENT: INDIA'S GROWING CRISIS OF GOVERNABILITY (1990).

100. See A. Noorani, Liquidation of Personal Liberty, 12 ECON. \& POL. WKLY 730, 731 (Apr. 30, 1977).

101. Atul Kohli, Can the Periphery Control the Center?, 19 WASH. Q. 115 (1996). 
In the early 1990s, growing political fault lines were emphasized by economic fractures created by the liberalization of India's economy. ${ }^{102}$ Though moves toward a more liberal economic policy were present in the early $1980 \mathrm{~s}$, it was the 1990s, and in particular the decisive move in 1992 to float the Indian currency, that truly moved India away from its central planning past, permanently disaggregating its economy. The disjuncture created by economic growth-most notably regarding mounting inequalities-has served to still further "decenter"103 the Indian federal state. Since the early 1990s, due to significant economic growth, its acquisition and testing of nuclear weapons, and its growing influence in trade and politics regionally and globally, the country has clearly entered into a new phase. It is no longer the country shaped by Congress' nation building and anti-colonization philosophy. Rather, it is a state that seems to be embracing the West and the wider international community, eager to be recognized as a developing "superpower" and deserving of a seat at the permanent bargaining table. ${ }^{104}$

Throughout India's independence, its Supreme Court has been one of the only national institutions to retain the wide base of support and legitimacy accorded to early Congress. Though constant, the turbulence of the events surrounding it over the past fifty years saw marked changes in the use of foreign law in Court decisions. Though they likely were only partly caused by them, the correspondence between political events and the use of foreign law by the Court is striking.

\section{iii. A Brief Note on the Powers and Prerogatives of the Indian Supreme Court}

The Supreme Court's constitutionally-granted powers are significant, but they are only a shadow of the powers the institution has assumed over time. The Court has original, appellate, and advisory jurisdiction. Its exclusive original jurisdiction extends to any dispute between the Government of India and a state, or between states. In addition, Article 32 of the Constitution gives an extensive original jurisdiction to the Supreme Court in regard to enforcement of fundamental rights. Indeed, when fundamental rights are implicated, the Indian Supreme Court ordinarily sits as a court of first instance.

What the Court is and what the Court was designed to be differ significantly. The constitution's framers wanted a clearly subordinate judiciary. During the constitutional debates, Nehru made this position unambiguous:

$[\mathrm{No}]$ judiciary can stand in judgment over the sovereign will of Parliament .... If we go wrong here and there it can point it out, but in the ultimate analysis, where

102. Douglas Hill, India: Development, Hegemony and Liberalisation 1 (Feb. 14-15, 2005) (unpublished manuscript, on file with the University of Wollongong), available at http://www.uow.edu.au/ kyliesm/pdf/6\%20more\%20(hill).pdf (last visited Apr. 30, 2005).

103. See Kohli supra, note 101; Ramesh Thakur, A Changing of the Guard in India, 38 ASIAN SURV. 603, 604 (1998).

104. See generally Atul Kohli, India: The Waking Giant, 19 WASH. Q. 101 (1996). 
the future of the community is concerned, no judiciary can come in the way.... [Ultimately] the whole Constitution is a creature of Parliament. 105

Since its early period of operation under the thumb of Congress, discussed infra at Part VI.A, the Indian judiciary has gone through an evolution in role and power, and in so doing, has become a unique adjudicative body that considers a wide range of social issues under the rubric of protecting fundamental rights.

V.

\section{EXAMINING THE SUPREME COURT OF INDIA's USE OF ForEIGN LAW}

\section{A. Introduction: Is Foreign Law Needed in the Indian Context?}

The resort to foreign law would be less intriguing - and likely less contentious-if it were evident that foreign law was "needed" in domestic jurisprudence. If there were noticeable lacunae in local law, reference to foreign courts would seem both reasonable and necessary. However, this does not seem to be the case in India. The Indian Constitution, the longest in the world, ${ }^{106}$ is extremely comprehensive, with nearly 400 articles and a further 83 amendments implemented since ratification in 1950. In its articles, the document guarantees an impressive array of fundamental rights covering a wide range of civil, political, cultural, economic, and social liberties. Further, the constitution has proven a surprisingly modern document, including within it prohibitions on specific discriminations, the institutionalization of an "affirmative action" program and the provision of social and cultural rights ${ }^{107}$ (in addition to the typical civil and political rights ensconced in most pre-World War II constitutions). ${ }^{108}$ Importantly, Indians are not only given rights, but are provided legal remedies - framed as rights themselves. These rights secure to every individual, citizens and aliens alike, the ability to invoke the Supreme Court's original jurisdiction for enforcing any fundamental right.

Moreover, the Constitution was a true post-World War II document, infused with human rights protections more explicitly expansive than in any prior compact. Part III of the document reflects these aspirations, mimicking the Universal Declaration of Human Rights (UDHR), which was adopted by the United Nations General Assembly in 1948. As a result, the constitution granted Indians many of the protections of the UDHR two decades before India became

105. Robert Moog, Activism on the Indian Supreme Court, 82 JUdiCATURE 124, 125 (1998) (quoting Jawaharlal Nehru).

106. See Gary Jacobsohn, Borrowing: The Permeability of Constitutional Borders, 82 TEX. L. REV. 1763 (2004).

107. Among other rights, the Indian Constitution provides the right to acquire, hold and dispose property (Article 33), to practice any profession, occupation, trade or business (Article 34), and to be free in religious thought, belief, practice, with a guarantee regarding "institutional existence" of religions (Article 51). The Constitution also vests the State with powers regarding religion, most notably to compel public Hindu temples to open their doors to all classes of Hindus (Article 53). Finally, the document also safeguards minority rights, with a "minority" comprising "any distinct religious, cultural and linguistic group" (Article 54).

108. Sunstein, supra note 92. 
a signatory to the 1966 covenants implementing the UDHR. ${ }^{109}$

Given the extensiveness and expansiveness of the constitution, it is evident that foreign law is not "needed" in India. The breadth of the constitution could be interpreted to cover the full scope of human activities. Yet, despite the comprehensive nature of the document, resort to non-domestic law became an early component of Supreme Court jurisprudence, with the use of foreign precedent closely following the historical and political developments in India.

\section{B. Dataset}

In order to assess the use of foreign law, each of the Supreme Court's 14,778 cases, ${ }^{110}$ heard from $1950-2005$, were examined for use of foreign law, a period in which the Indian Supreme Court saw a steadily increasing caseload (see Figure I). "Foreign law" was defined as any law not emanating from the Indian parliament, an appropriate definition given the state's history of parliamentary supremacy. Specific foreign systems examined include English law (including the Privy Council, regardless whether India was a party in the cited case), United States law, Canadian law, Australian law, Commonwealth provisions, ${ }^{111}$ international law writ-large (including specific treaties as well as customary international law), religious law, and academic treatises. "Use" of foreign law was defined as any sort of positive or neutral citation to nondomestic precedent or principle. The preliminary results are recorded in Table I.

\section{Table I}

\section{Indian Supreme Court Cases Citing Specific Foreign Law 1950-2004}

\begin{tabular}{lllllllllll} 
& TOTAL & English & Privy & \multicolumn{3}{c}{ U.S. Canadian Australian } & \multicolumn{2}{l}{ Commw. Int'l } & \multicolumn{2}{c}{ Religious Academic } \\
& & Law & Council & Law Law & Law & Law & Law & Law & Treatises \\
Number & 3629 & 751 & 2543 & 1019 & 174 & 279 & 154 & 168 & 24 & 10 \\
Percent & 24.6 & 5.1 & 17.2 & 6.9 & 1.2 & 1.9 & 1.0 & 1.1 & 0.2 & 0.1
\end{tabular}

109. The Indian Constitution also leans heavily on rights that would become the International Covenant on Civil and Political Rights. Such rights include: Freedom of Speech, Movement, Peaceable Assembly, Thought and Religious Conscience; Freedom from Discrimination, ex post facto Legislation, Double Jeopardy, Compulsory labor; Self-incrimination, Equality, Access for Public Services, to Choose One's Own Residence, and Legal Remedies. See Sripati, supra note 87.

110. This represents all reported judgments of the Indian Supreme Court from 1950 through 2004 available on the Court's Judgment Information System. See Indian Courts Judgment Information System, http://judis.nic.in.

111. "Commonwealth" law refers to citations reliant on the laws of Commonwealth states other than Australia and Canada. See, e.g., State of Bihar v. Kameshwar Prasad Verma, A.I.R. 1965 S.C. 575, 577 (citing the Nigerian case, Eshugbayi Eleko v. Officer Administering the Gov't of Nigeria [1931] A.C. 662). 
Figure $I^{12}$

Indian Supreme Court Caseload (1950-2004)

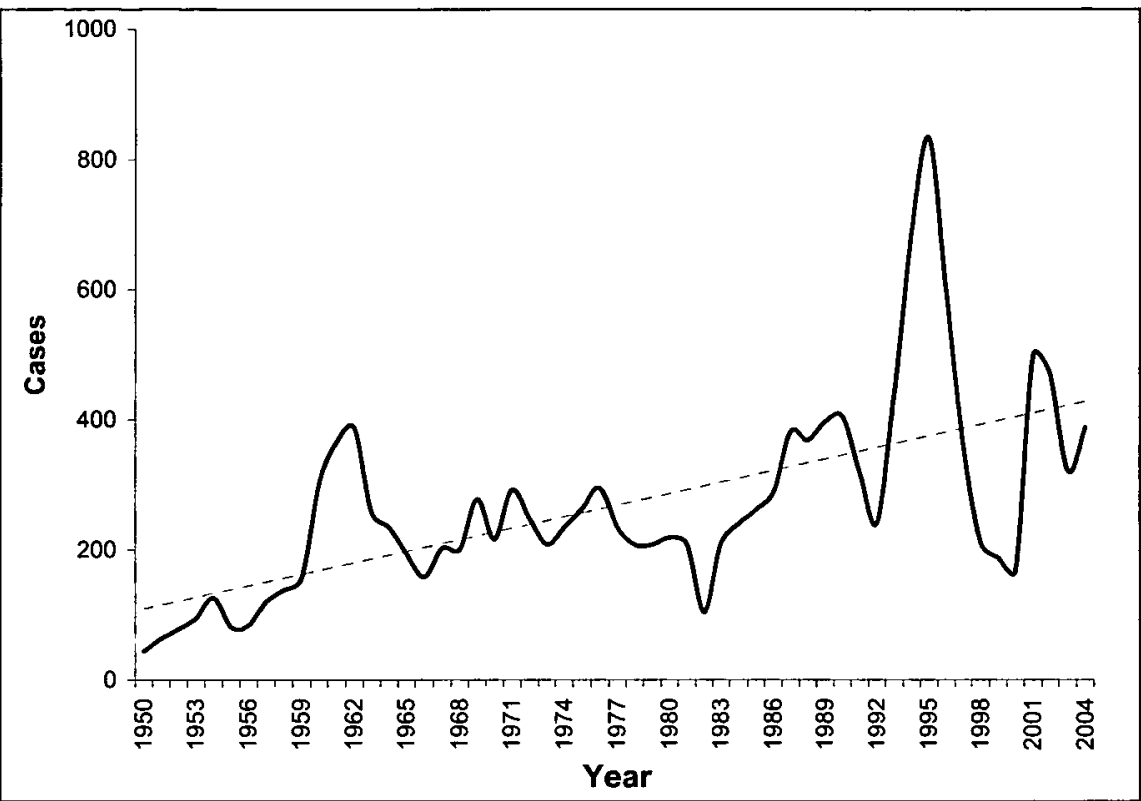

C. Overall Decline

Though one quarter of all Indian Supreme Court judgments have relied on foreign law, the use of foreign precedents has not been consistent since 1950. As indicated in Figure II, the use of foreign law has undergone a drastic decline since the start of the Court, when almost sixty-five percent of cases relied on foreign citations, to a low in the mid-1990s when fewer than nine percent of judgments did so. Though foreign citations have recovered from their 1995 low, the larger trend since 1950 remains clear: the Indian Supreme Court is relying less and less on foreign law.

112. Trend lines in the following figures are generated by calculating a linear, "best fit" line to the data. 


\section{Figure II}

\section{Indian Supreme Court Cases Citing Foreign Law (in percent) (1950-2004)}

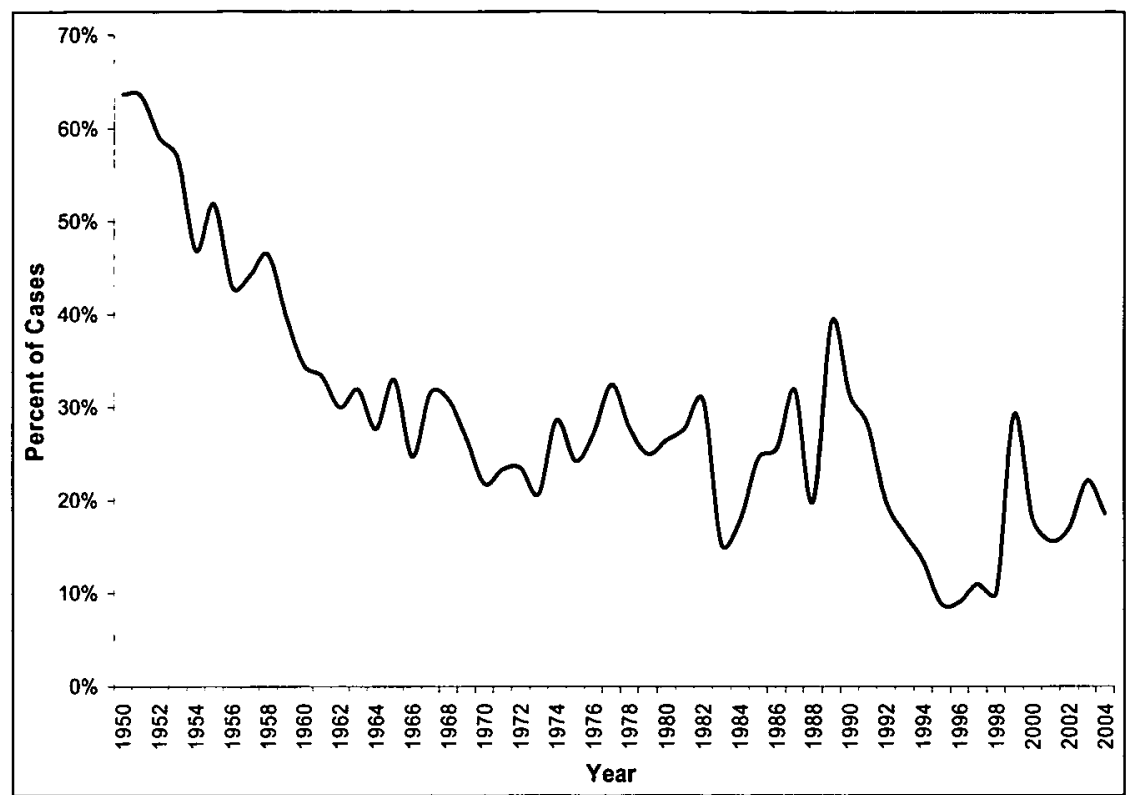

The task of the remainder of this paper is to explain this decline, and shed light on some of the undulations along the way. This section will proceed by analyzing two complementary explanations for this decline in India-the inevitability of decline and the use of foreign law as a proxy for state development. While not dismissing the first hypothesis, the bulk of the analysis addresses the second theory of foreign law usage.

\section{Explanation One: The Inevitable Rise of Domestic Jurisprudence}

Though the correlation between the historical and political events described above and the use of foreign law in India is strong, a significant part of the marked decline in resort to foreign law can be attributed to the "inevitability" of the creation of domestic jurisprudence, and the consequent increase in reference to "home-grown" decisions. The creation of jurisprudence is a time-consuming, incremental process. However, over time, especially in a common-law system beholden to stare decisis, a new court will tend to rely to an ever greater degree on its own precedents. ${ }^{13}$ The advantages of developing and using a body of

113. See generally David Strauss, Common Law Constitutional Interpretation, 63 U. CHI. L. REV. 877 (1996); David Strauss, Freedom of Speech and the Common-Law Constitution, in 
domestic precedents go beyond the psychological benefits gained from establishing a robust, independent court system. There is evidence that, in as much as the use of domestic precedent increases the stability and predictability of courts' decisions, it also reduces information costs and positively impacts economic growth. ${ }^{114}$

The same phenomenon of reduced foreign law citations, likely for similar reasons, has been found in examinations of nascent periods of other constitutional courts, including the U.S. Supreme Court. Explaining his heavy reliance on foreign precedent, Justice Joseph Story (who served on the bench from 1811 to 1845) argued that "[foreign law] offered a reservoir of solutions to problems that American law had not yet faced."115 As America advanced, and its own "reservoir" of solutions grew, the need for foreign law declined. More recently, this trend of declining reliance on foreign law can be seen in the constitutional courts of Canada and South Africa. ${ }^{116}$

Although the South African Constitution and the Canadian Charter of Rights and Freedom arose from different circumstances, and although the two countries had divergent histories with respect to protection of civil liberties, at the time Canada and South Africa adopted their new constitutions, neither Canadian nor South African jurists were experienced in the art of judicial review of fundamental rights. ${ }^{117}$ Further, they had little existing case law to apply to these issues. Because their largely English heritages had neither judicial review nor an entrenched bill of rights, the judges were not equipped with sufficient doctrinal knowledge to effectively engage with the new constitutional debates. As a result, especially in early cases, it made sense for both Canadian and South African judges to consider foreign sources. ${ }^{118}$

Judges of both courts conceded this initial need for foreign law. For example, in South Africa's 1995 death penalty case, State v. Makanyane, Justice Arthur Chaskalson argued that "comparative... jurisprudence will ... be of importance, particularly in the early stages of the transition when there is no developed indigenous jurisprudence."119 In Canada, Justice Beverley

Eternally Vigilant: Free SPEech IN THE MODERN ERA 32 (Lee C. Bollinger \& Geoffrey R. Stone eds., 2002); David. Strauss, The Irrelevance of Constitutional, Amendments, 114 HARV. L. REV. 1457 (2001).

114. Aymo Brunnetti et al., Credibility of Rules and Economic Growth, The World Bank Policy Research Working Paper No. 1760 (1997) (on file with author).

115. Shael Herman, Book Review: Consilia: A Bibliography of Holdings in the Library of Congress and Certain Other Collections in the United States, 63 TUL. L. REV. 1249, 1251 (1989).

116. Shannon Smithey, A Tool, Not a Master: The Use of Foreign Case Law in Canada and South Africa, 34 COMP. POL. STUD. 1188, 1199-1200 (2001).

117. Id. at 1194-95.

118. However, Justice La Forest argues that while the short history of the Canadian legal tradition may at one point have made it necessary for Canadian courts to look beyond their borders for law, more recent use of foreign law stems from a genuine interest: "Necessity has been replaced by a sincere outward-looking interest in the views of other societies, especially those with traditions similar to ours." Gerard V. La Forest, The Use of American Precedents in Canadian Courts, $46 \mathrm{ME}$. L. REV. 211,212 (1994).

119. State v. Makwanyane, 1995 (6) BCLR 665 (CC), $\{37$ (S. Afr.) (emphasis added). 
McLachlin contended that the "difficulty is that the Canadian Charter... is a new experience," and Canadian "judges [consequently] cannot rely on their own experience ...; instead, they must ... [look] elsewhere."120

The judges' lack of expertise and experience in constitutional rights jurisprudence reinforced the South African and Canadian constitutions' encouragements of resort to comparative law. Chapter 2, Section 39(1) of the South African Constitution declares that:

When interpreting the Bill of Rights, a court, tribunal or forum (a) must promote the values that underlie an open and democratic society based on human dignity, equality and freedom; (b) must consider international law; and (c) may consider foreign law. ${ }^{121}$

The Canadian Charter is not as specific about the consideration of external sources. It does imply, however, a role for foreign precedent by declaring that "[the] Canadian Charter... guarantees the rights and freedoms set out in it subject only to such reasonable limits prescribed by law as can be demonstrably justified in a free and democratic society." 22 Surveying the case law of other "free and democratic" societies is one way to determine what limits are reasonable. $^{123}$ Further, for some observers, that the Charter explicitly borrows clauses and ideas from other jurisdictions-notably, its reliance on the American Constitution's Fourteenth Amendment due process clause-suggests encouragement of the use of foreign jurisprudence. ${ }^{124}$ Moreover, it was widely felt that the introduction of the Charter was a fundamentally "new way to think about law," and thus its framers likely assumed that judges would, at least initially, turn to those jurisdictions with longer histories of interpreting such rights. 125

The Indian judiciary was also ill-prepared for the judicial review powers their constitution granted them, which made resort to foreign principles a natural reaction. The Indian Constitution also promoted such reliance. Partly this was a function of Article 372(1), which provided for the continued operation of laws that had been in force prior to the constitution. These laws included not just those officially promulgated but also a vast body of common law extant in England-including customary international law ${ }^{126}$ - that was thought to be

120. Beverley McLachlin, The Charter of Rights and Freedoms: A Judicial Perspective, 23 B.C. L. REV. 579,580 (1989).

121. S. AFr. ConST. 1996 Chapt. 2 , § 39(1).

122. Canadian Charter of Rights and Freedoms, Part I of the Constitution Act, 1982, being Schedule B to the Canada Act 1982, ch. 11, art. I (U.K.).

123. Smithey, supra note 116.

124. Jonathan L. Black-Branch, O Canada, Our Home on Native Land: Aboriginal Self Government, Not the 'Canadian Charter of Rights and Freedoms,' May be the Key to Educational Reform, 14 CAN. J. OF NATIVE STUD. 280, 284 (1993), available at www.brandonu.ca/Library/CJNS/13.2/Black-Branch.pdf (last visited Apr. 30, 2005).

125. Noel Lyon, The Charter as a Mandate for New Ways of Thinking about Law, 9 QUEEN'S L.J. 241 (1984).

126. Regarding international conventional or treaty law, India subscribes to the dualist position; such agreements have no binding effect unless implemented by legislation. The Supreme Court reiterated this position in Jolly George Varghese v. Bank of Cochin (1980) 2 S.C.C. 360. 
part of the legal inheritance that Britain bequeathed to India. Additionally, the combination of Article 41(c), which calls for the state to foster respect for international law, and Article 147, which mandates that, in matters of interpretation, the Supreme Court look to pre-Independence legislation, suggests that reference to foreign law was to be expected.

Foreign law also plays an important role in comparing the current South African and early Indian experiences. Though for different reasons, both the South African and Indian Constitutions try to distance themselves from their pasts and establish their legitimacies on the world stage. Regarding the former, the South African preamble explicitly recognizes the country's apartheid past, ${ }^{127}$ using it as a rationale for the constitution, while the Indian document relies on solemn implicit and explicit calls for full independence to spur it onward. Establishing legitimacy was often intertwined with breaking from the past. Justice Mokgoro's opinion in Makwanyane mentions that the repressive nature of white rule was the reason for the absence of useful domestic precedent on the issue of the death penalty, and that consequently South Africa must look to "internationally accepted values" for guidance in creating its human rights jurisprudence. ${ }^{128}$ In India, a healthy initial reliance on English law was thought to serve the same purposes, allowing Indian judges to adapt English common law to the domestic arena, while assuring the international community of the soundness of its jurisprudence.

Under the "inevitability" explanation for the decline in use of foreign law, the combination of judicial expertise, constitutional requirements and, in the South African and Indian cases, desire for respect on the world stage, led to early and significant use of foreign law. However, once legitimacy was less parlous and a domestic corpus of law had been developed, the impetus quickly

127. The preamble of the Constitution of South Africa reads: "We, the people of South Africa, Recognise the injustices of our past; Honour those who suffered for justice and freedom in our land ....We therefore, through our freely elected representatives, adopt this Constitution as the supreme law of the Republic so as to - Heal the divisions of the past and establish a society based on democratic values, social justice and fundamental human rights." S. AFR. CONST. 1996, Preamble.

128. State v. Makwanyane 1995 (6) BCLR 665 (CC), I 304 (S. Afr.). Several other cases in South Africa have also sought to draw a sharp line between the apartheid past and the present. See, e.g., State v. Williams 1995 (3) SA 632 (CC), 152 (S. Afr.) (describing the apartheid state as a bad role model and calling for the new state to take the lead as 'model citizen'); Ferreira $v$. Levin 1996 (1) SA 984 (CC), I 51 (S. Afr.) (describing apartheid as repressive and arbitrary and favoring broad protection of liberty and dignity); Lawyers for Human Rights v. Minister of Human Affairs 2004 CCT 18/03 (CC), I 36 (S. Afr.) (stating that the apartheid practice of detention without trial should 'never again' be allowed and favoring a broad and substantive definition of the right not to be subject to arbitrary detention); Case v. Minister of Safety and Security 1996 (5) BCLR 608 (CC), I 100 (S. Afr.) (stating that privacy should be given expansive protection given the apartheid history of invading privacy with impunity); Larbi-Odam v. Council for Educ. 1997 (12) BCLR 1655 (CC), I 19 (S. Afr.) (associating denial of citizenship to permanent residents with racially manipulative Bantustan policies); Dawood v. Minister of Home Affairs 2000 (3) SA 936 (CC), I 35 (S. Afr.) (describing how dignity was "cruelly" denied under apartheid" and expressing a commitment to the dignity center of transformative constitutional project); Volks v. Robinson 2005 (5) BCLR 446 (CC), I 107 (S. Afr.) (stating how historical discrimination against certain kinds of marriage means that broad interpretation ought to be given to prohibition against discrimination on grounds of marital status). 
shifted to the use of domestic precedent, for reasons of both national pride and efficiency.

\section{E. Explanation Two: Foreign Law as a Marker for State Transformation}

In the Indian case, a significant portion of the overall decline in the use of foreign law is likely explained by the inevitability theory. However, this hypothesis does not explain the undulations in usage of foreign law, the various rates of usage of case law from different countries, nor the more recent increase in foreign law usage in India. Rather, the intricacies of foreign law usage can be more fully explained only by broadening the investigation to examine how foreign law usage fits into the overall course of India's political and legal history.

The presence of very different trends regarding the use of particular types of foreign law in Indian Supreme Court judgments constitutes primary support for the thesis that the use of foreign law is more than a simple stop-gap until states develop their own internal jurisprudence. Figure III shows the comparison between the Indian Court's references to English law, which is historically the most cited foreign jurisdiction in Indian case law, and American law, which, until recently, was the second most referenced non-municipal system.

\section{Figure III}

Indian Supreme Court: Cites to English Law vs. Cites to U.S. Law (19502004)

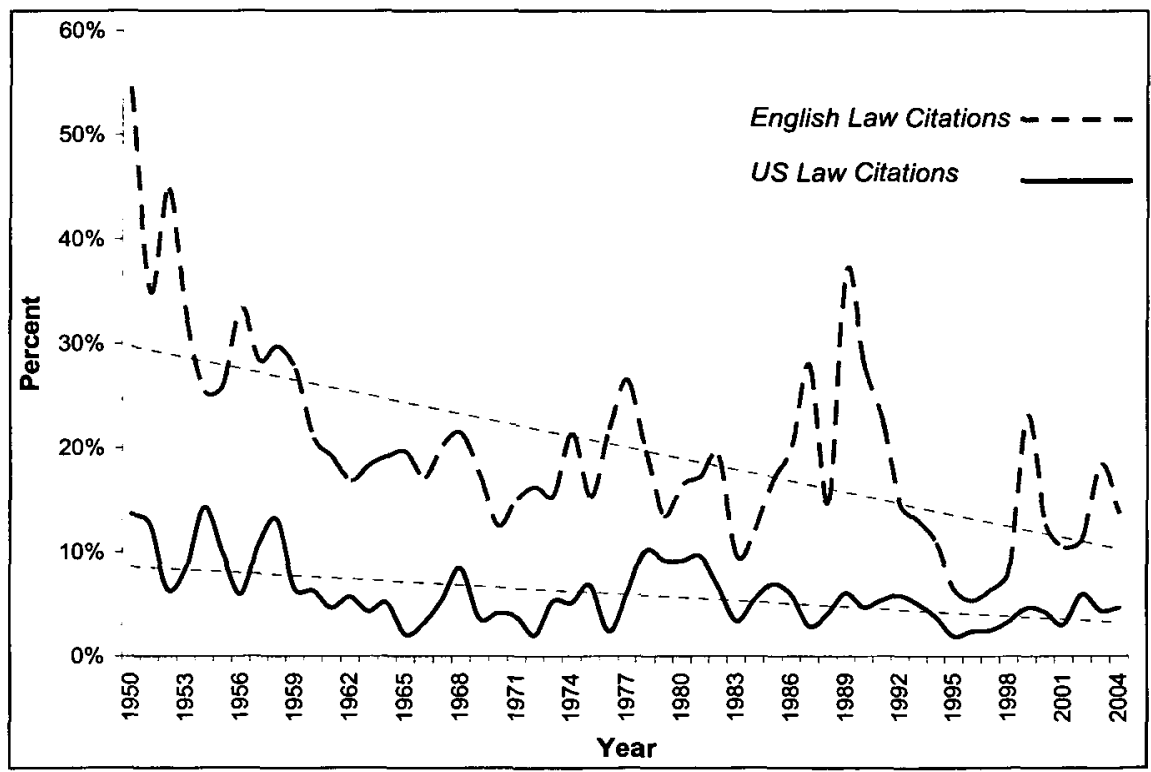


Again, the comparative declines could be attributable to the same inertia of development described above, with the steeper decline of English law resultant solely from its much higher proportion at the start of independent India. However, the degree of difference and variance between citations to English compared to American law seems too great to be so simply accounted for. Reference to English law has declined four times as rapidly as citations to U.S. law. Further, reference to U.S. law has been comparatively stable throughout the period, with American citations appearing in about six percent of cases, but varying very little annually (between two percent and fourteen percent). English law is cited in approximately twenty percent of cases, but in given years, this figure has varied from nearly fifty-five percent of cases to just over five percent. Moreover, there is a marked leveling of reference to English law that appears to have started in the 1980s, with significant expansion of such references (to levels seen decades earlier) in the last ten years. This same resurgence can be seen in Figure II with reference to the use of foreign law in general, but has not occurred regarding the use of American law. These trends suggest that India has had a different relationship over time with law emanating from its colonizer, by contrast with law from elsewhere, and between foreign laws in general and domestic precedent. The machinations of politics, economics, and law provide a convincing explanation of what may be behind these phenomena.

VI.

THE THREe STAgES OF POST-INDEPENDENCE HISTORY REFLECTED IN THE COURT'S JURISPRUDENCE

Post-independence Indian history can be separated into three periods: ${ }^{129}$ the years from Independence until the end of the Emergency in 1977; the period from the end of the Emergency until the demise of central planning and the opening-up of the state in the early 1990s; and finally from the 1990s until the present, during which time India has become increasingly exposed to the forces of globalization. Although these divisions are inexact, and certain core state characteristics have always been present, the tripartite split provides a good understanding of the primary themes and challenges faced during each period.

Briefly, as illustrated in Figure IV, the three periods comprise (1) 19471977 (the post-independence, nation-building era in which the state experienced strong Congress Party hegemony), (2) 1978-1991 (the post-Emergency period, which saw the fall of the Congress Party and the rise of political and economic

129. Separating India's history in such a manner takes into account the primary political and economic inflections since 1947 and broadly follows the models used in Iqbal Narain, India 1977: From Promise to Disenchantment?, 18 ASIAN SURV. 103 (1978), and S.P. SATHE, JUdICIAL ACTIVISM IN INDIA (2002). Other scholars, such as Bruce Ackerman, opt for a broader separation of Indian history into five periods. See Ackerman, supra note 14. 
fragmentation), and 1992-present (which has seen a radical departure from the past, beginning with the floating of the Indian currency and proceeding with the further economic, cultural, and social opening up of India to the world, and the consequent reaction of the world to India. Mapping foreign law citation onto this history is enlightening.

During the first period, following an initial reliance on foreign law due to the expertise and constitutional issues described above, the Court was cajoled and cowed by Congress Party leaders and moved by members of the Court committed to Congress ideals into quickly departing from foreign law usage in an attempt to build up and legitimate the independence of the state. During the second period, as a direct result of the excesses under the Emergency and the non-fulfillment of fundamental rights protections, the Court became activist, markedly expanding the range of protections. Though domestic jurisprudence was important, foreign law became a critical component in this process, and its use saw a marked increase. Finally, since 1992, the Court's (and the country's) involvement with the outside world has grown, but so too has the ambivalence with which the state faces the international community. The result has been the emergence of jurisprudence protecting "secondary" rights-particularly social and cultural rights-implicated by the process of globalization. This result, combined with instability within the country, which in turn put pressure on some of the "primary" civil and political rights that received support between 1978 and 1991, correlates with vast fluctuations in the use of foreign law by the Court.

\section{Figure IV}

Three Stages of India's Post-1950 History and Foreign Law Citations

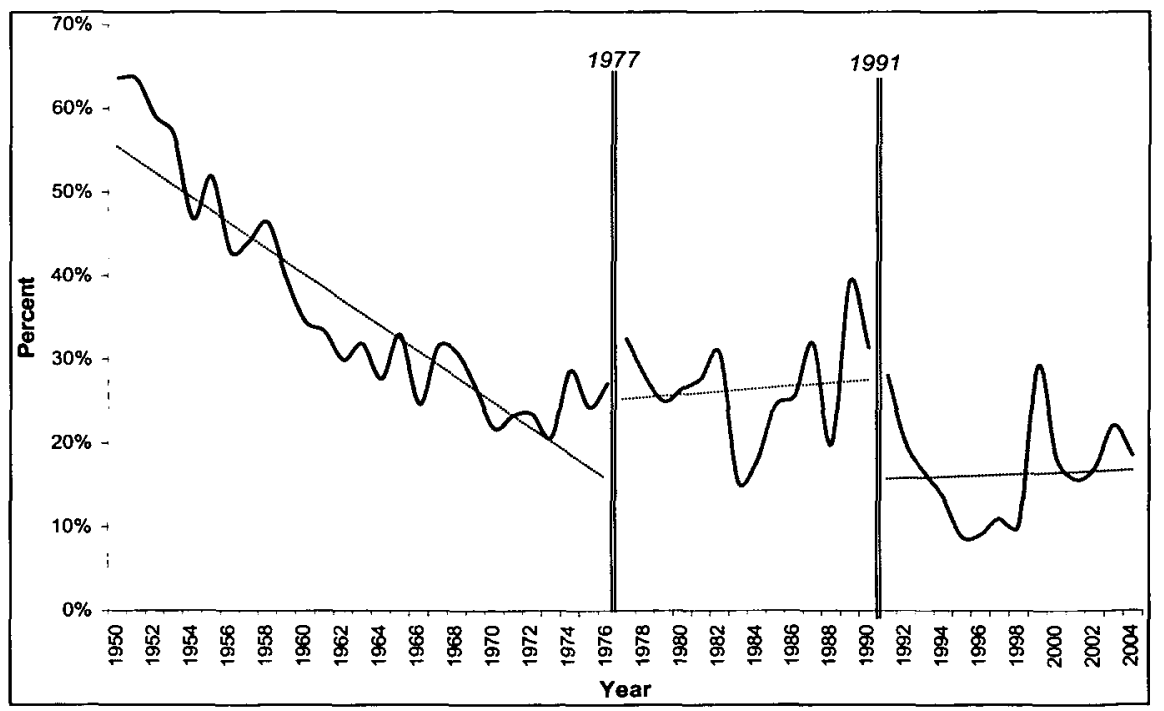




\section{A. 1947-1977: Post-Independence and the Imperative of Nation Building}

The cases heard by the Supreme Court during this formative period both directly reflected the preoccupations of society during the time and, like the emerging precedents that resulted, were in line with the nation-building ethos instigated by the Congress Party. Clear subservience of the Court to the government-under the rubric of a "committed judiciary"130 — was the preeminent mode during this period. The combination of institutional pressures to support the government's program of development-which included a broadly expressed fear of institutional invalidation if the Court did not support the government ${ }^{131}$ - and the existence of patronage, made the judiciary significantly less powerful than its broad rights of judicial review might suggest.

The first justices of the Indian Supreme Court functioned in a manner similar to their English counterparts, hesitant "to assume [broad] . . powers for the Court."132 Most members of the Court during the 1950s and 1960s believed that the Nehru government needed time and latitude to enact its economic, political, and social agenda. ${ }^{133}$ This belief fomented an institutional weakness in comparison with the other branches of government, underscored by the Court's 1950 decision in A.K. Gopalan v. State of Madras. ${ }^{134}$ In that case, a petitioner challenged the validity of the Preventive Detention Act on the grounds that it violated his right to life, protected by Article 21 of the Indian Constitution. However, the Court interpreted Article 21 like any other statemade law, rather than an abstract principle of natural justice. This led the Court to hold that the impugned act-a law duly enacted by Parliament-did not violate Article 21.

Such consequentialist decisions disempowered the Supreme Court and all but formally enlisted it in the process of nation building (in the Congress Party mold) alongside other organs of the state. Gopalan and its progeny ${ }^{135}$ reflected both an institutional insecurity-the Court's concern with its place in society if the political branch were to brand it a tool of elites rather than the people ${ }^{136}$ and the fact that Congress' philosophy also became ingrained in many of the

130. This was a telling neologism coined by Congress Party Ministers. See H.M. SEERvIA, CONSTITUTIONAL LAW OF INDIA: A CRITICAL COMMENTARY 2405, n.57 (4th ed. 1996).

131. See generally M.P. Singh, Securing the Independence of the Judiciany-The Indian Experience, 10 IND. INT'L \& COMP. L. REV. 245 (2000).

132. Sathe, supra note 129 , at 6.

133. S.P. Sathe, Judicial Activism: The Indian Experience, 6 WASH. U. J.L. \& POL'Y 29, 41 (2001).

134. A.I.R.1950 S.C. 27. Notably, the judges rejected the relevance of foreign case law in the face of arguments that Article 21 was based on other constitutions' due process provisions. After all, had such case law been considered, the limited nature of the court's holding would have been clear. In the American case, see, for example, Murray's Lessee v. Hoboken Land \& Improvement Co., 59 U.S. 272 (1855) (holding that Congress is not free to make any process "due process" of law).

135. This line of cases concluded with the "total demise" of the Court's institutional power, recorded in A.D.M. Jabalpur v. Shivakant Shukla, A.I.R. 1976 S.C. 1207. See Sathe, supra note 133, at 43 .

136. Sathe, supra note 133 , at 50 . 
justices. In addition to the Gopalan line of cases, parliamentary control over the Court saddled it with structural weaknesses, including "two supersession crises (regarding appointments to the chief justiceship) ..., the passage of the FortySecond Amendment to the Constitution, limiting its scope of judicial review,"137 and the transfer of "inconvenient judges."138 Parliament even broached the idea of replacing the body with a more compliant Constitutional Court. $^{139}$

Even if the Supreme Court were to challenge Parliament - as it did even in the early period on issues primarily related to property rights-the ease with which the Parliament amended the constitution regularly rendered the Court moot. ${ }^{140}$ As a result, despite a few cases to the contrary in which the Court attempted to assert judicial powers, ${ }^{141}$ the bench all but refused to challenge parliamentary power during the first decades of independence. It would take more than two decades to redress this imbalance between the legislature and the judiciary.

The nadir of the Court's acquiescence to Parliament came in the 1976 case A.D.M Jabalpur v. Shiv Kant Shukla, ${ }^{142}$ which provided legal cover for Prime Minister Indira Gandhi's imposition of the Emergency. ${ }^{143}$ Shiv Kant Shukla arose from habeas corpus petitions submitted by political prisoners detained under the Prime Minister's emergency powers. Ruling for the government, the Court denied the petitions and effectively abrogated all law "in relation to life and personal liberty."144

In the Court's role as supporter of parliamentary action rather than enforcer

137. Robert Moog, Judicial Activism in the Cause of Judicial Independence: The Indian Supreme Court in the 1990s, 85 JUDICATURE 268, 270 (2002).

138. Sathe, supra note 133, at 30.

139. Moog, supra note 137, at 270.

140. See generally Neal A. Roberts, The Supreme Court in a Developing Society: Progressive or Reactionary Force?, 20 AM. J. COMP. L. 79 (1972).

141. Three cases are of note: (1) Golak Nath v. State of Punjab, A.I.R. 1950 S.C. 27 (ruling that parliament could not curtail any of the fundamental rights in the Constitution); (2) Indira Nehru Gandhi v. Raj Narain, A.I.R. 1967 S.C. 1643 (implementing Golak Nath's holding); (3) Kesavananda Bharathi v. State of Kerala, A.I.R. 1973 S.C. 1461, 1463 (placing an effective break on the trend of unquestioned parliamentary control by enunciating a doctrine of inviolability of the Constitution's "basic foundation and structure"). Despite these and other cases, the court's activism was tempered. Thus, although between 1950 and 1975 the Indian Supreme Court had held more than one hundred Union and State laws, in whole or in part, to be unconstitutional (in contrast to the U.S. Supreme Court, which had between 1790 and 1985 only held 135 federal and 970 state laws, in whole or in part, to be unconstitutional), parliament often succeeded in legislating around the unconstitutional provisions, either ignoring the court or passing new amendments. For instance, parliament responded to the setback in Golak Nath by passing the Twenty-Fourth Amendment. See Sathe, supra note 133 , at 42.

142. A.I.R. 1976 S.C. 1207.

143. The irony in the Court's supporting the Emergency is that an immediate precipitant of the Emergency was a high court ruling finding Prime Minister Gandhi guilty of election code violations stemming from her 1971 campaign. Moog, supra note 105, at 126.

144. Lester, supra note 12, at 545 (quoting A.D.M. Jabalpur v. Shivakant Shulela, 2 S.C.C. 521 (1976)). That the Court was effectively cowed during this period became evident after the emergency and the mea culpa offered by some judges who had supported the government. 
of rights, it is not surprising that it turned so sharply away from foreign law. First, the majority of law formed in the immediate post-World War II erainformed by the Holocaust and a growing sense of human rights norms-would not fit the needs of the Court. Second, the sharp decline of English law, yet the comparative stability of other sources of foreign law, is also indicative of the seeming requirements of nation building. In the independence period, especially as long as the leadership of the independence movement remained in power, many viewed a repudiation of the colonizer as the key to making the former colony a real nation.

This first stage of Indian jurisprudence is matched to some degree by the present experiences in Canada and South Africa, both countries whose courts are arguably in the midst of this early post-constitution period. Though neither Canada nor South Africa have the added fuel of "independence," nor have been forced to face a uniformly recalcitrant parliament, the similarities of concerns from Canadian and South African judges regarding the type of foreign law being used, and the resulting developing case law, is remarkably consonant with the Indian post-Independence experience.

Though judges in both Canada and South Africa have admitted their reliance on foreign precedent, see supra Part V.D, jurists in both countries have also become manifestly sensitive to both perceived over-reliance on foreign jurisprudence in general and/or the jurisprudence of particular countries. For example, in South Africa, Judge Pius Langa argued that "our ultimate definition of these concepts must necessarily reflect our own experience and contemporary circumstances as the South African community." 145 In Canada, the concern has been in separating Canadian jurisprudence both from its English roots and American influence. Justice Gerald La Forest insisted that judges "should be wary of drawing too ready a parallel between constitutions born to different countries in different ages and in very different circumstances .... American jurisprudence, like the British, must be viewed as a tool, not as a master."146 To some, cases in which Canadian jurisprudence diverges from the U.S. model have even been cause for celebration. ${ }^{147}$

The balance between developing domestic law and resorting to foreign precedent has been more difficult for South Africa and Canada than it has been for India, given the meek support for fundamental rights expressed by the Indian Court in the post-Independence period. For South Africa and Canada, where the provision of rights has been enforced, it has clearly been challenging to

145. State v. Williams, 1995 (3) SA 632 (CC), ๆ 23 (S. Afr.).

146. Rahey v. Regina, [1987] 1 S.C.R. 588, 639.

147. Such "rejoicing" seemed to follow the Supreme Court's rejection of the American model of libel promulgated in New York Times v. Sullivan, 376 U.S. 254 (1964). Owen Fiss argues that, "To its great credit, the Supreme Court of Canada has avoided the libertarian interpretation of free speech that has so controlled American jurisprudence for the last two decades." Owen Fiss, Speak, Canada, Speak: A Convocation Address to the Class of 2004, University of Toronto (June 7, 2004), http://www.law.utoronto.ca/alumni_frnds_content.asp?itempath $=4 \% 2 \mathrm{~F} 23 \% 2 \mathrm{~F} 2 \% 2 \mathrm{~F} 1 \% 2 \mathrm{~F} 0$ \& contentId $=1000$. 
simultaneously invoke persuasive, legitimacy-enhancing foreign law, while building up internal jurisprudence. One of the common solutions in both states, reflecting the India Supreme Court's approach to "fundamental rights" cases, ${ }^{148}$ has been for judgments to refer to a substantial number of foreign jurisdictions, but rely on only a few, if any, when making the decision. For instance, in President of the Republic of South Africa $v$. Hugo, judges debated and essentially rejected precedents from Britain, New Zealand, Australia, Germany, and the United States on the ground that courts have the authority to review acts of executive prerogatives. ${ }^{149}$ Likewise, in a Canadian libel case, Hill $v$. Church of Scientology of Toronto, the Court discussed the American definition of the tort at length before explicitly refusing to follow the American model. ${ }^{150}$

This balancing is related to the fact that both courts appear to view citation, or non-citation, to specific jurisdictions as distinct components of their assigned national roles. In the case of Canadian, this involves a frequent rejection of U.S. case law, which is a corollary to Canada's larger political goals of differentiation vis-à-vis the United States. ${ }^{151}$ In South Africa, this has increasingly involved citation to other African cases--to further post-apartheid South Africa's goals of reintegration with the continent-, and a simultaneous emerging ambivalence regarding the use of American decisions. ${ }^{152}$

\section{B. 1978-1991: The Demise of Congress and the Rise of Individual Rights}

With the fall of Congress, the communitarian spirit of the party-and thus of the nation while the party was ascendant-also faltered. The "socialist" republic proposed ${ }^{153}$ in the Constitution's preamble gave way to a new focus on individual rights. In the political context, this led to the factionalization of the state and the emergence of class, caste, and regional political parties and interests. ${ }^{154}$ With the fall of the political system that pressured it to act, the

148. See A.K. Gopalan v. State of Madras, A.I.R 1950 S.C. 27 (referencing, but rejecting, the accepted interpretations of, inter alia, American, Japanese, English, Nigerian, and Australian case law).

149. President of the Republic of South Africa v. Hugo, 1997 (6) BCLR 708 (CC) (S. Afr.).

150. Hill v. Church of Scientology of Toronto, [1995] 2 S.C.R. 1130.

151. See, e.g., J.L. GRANATSTEIN, YaNkEE Go Home? Canadians and ANTIAMERICANISM (1998).

152. See, e.g., State v. Williams, 1995 (3) SA 632 (CC), 97 30-31 (S. Afr.) (arguing that the Namibian and Zimbabwean experiences are of particular value to South Africa's analysis of the matter at hand); Bhe v. Magistrate, Khayelitsha and Others, 2005 (1) SA 580 (CC) (S. Afr.) (making extensive references to the Zambian Constitution and engaging in a broad survey of African law); Lawyers for Human Rights v. Minister of Home Affairs, 2004 (4) SA 125 (CC) (S. Afr.) (including significant comparative analysis but notably without any U.S. references). Richard C. Blake, The Frequent Irrelevance of U.S. Judicial Decisions in South Africa: National Coalition for Gay and Lesbian Equality v. Minister for Justice, 15 S. AFR. J. HUM. RTS. 192, 197 (1999).

153. Though the term "socialist" was actually only added to the preamble in 1976 (via the Forty-Second Amendment) by Indira Gandhi, it is evident from Nehru's early speeches and the structure of the Congress Party that socialism always served as a critical organizing philosophy for the party/state.

154. This process has been deemed the "deinstitutionalization" of India and literature on this phenomenon is copious. See, e.g., Atul Kohli, State-Society Relations in India's Changing 
Court emerged as not only one of the few remaining "national" institutions, but also as a body significantly ennobled and empowered. As Robert Moog has noted:

In such a fluid ... environment the political branches of government [became] less of a threat to the courts and, ironically, more reliant on them as a possible source of legitimacy .... As opposed to most other governing institutions ... the court... [proved]... remarkably adept at building a constituency and accumulating good will.

The imposition of the Emergency in 1975 was a turning point in both the life of the state and the Supreme Court, leading to the Court's increased power and activism. In the post-Emergency era, the Court, sensitized by the perpetration of large-scale atrocities during the Emergency, donned an explicitly liberal mantle. In a series of decisions, the Court widened the scope of constitutional provisions to enforce the human rights of citizens and sought to bring Indian law into conformity with global trends in human rights jurisprudence. Foreign law played a significant role in this process.

Key aspects of this new jurisprudence-dubbed "judicial populism"156 were buttressed by innovative expansions in procedure and remedy, themselves resting on non-domestic notions of freedom and access to courts. Regarding procedure, this era saw India become one of the most liberal states in the world in terms of standing, ${ }^{157}$ giving birth to the vibrant Legal Aid and Public Interest Movement that has been behind much of the rights-based litigation. ${ }^{158}$ Importantly, and unlike many other states, it has been the Indian judiciary-not the Bar or civil society - that has been the primary driver behind this expansion in locus standi. In arguing that "processual jurisprudence [was] not too jejune to respond to societal changes and challenges," 159 the Court relied on several

Democracy, in INDIA's DEMOCRACY: AN ANALYSIS OF CHANGING STATE-SOCIETY RELATIONS (Atul Kohli ed., 1988); JOEL MIGDAL, STRONG SOCIETIES AND WEAK STATES: STATE-SOCIETY RELATIONS AND STATE CAPABILITIES IN THE THIRD WORLD (1988); and Rajni Kothari, Interpreting Indian Politics: A Personal Statement, in CRISIS AND CHANGE IN CONTEMPORARY INDIA (Upendra Baxi et al. eds., 1995). Not surprisingly, this process also resulted in the decline in prestige of the central institutions, still furthering the Court's power. Observers noted "general apathy among [parliament's] members, Ministers and public at large towards the work of Parliament. Absenteeism among members has assumed alarming proportions and defections for money and office have been a common phenomenon." Subhash Kashyap, Institutions of Governance: the Parliament, the Government and the Judiciary, in PROBLEMS OF GOVERNANCE IN SOUTH ASIA 89, 138 (V.A. Pai Panandiker ed., 2000).

155. Moog, supra note 137 , at 270.

156. Upendra Baxi, Taking Suffering Seriously: Social Action Litigation in the Supreme Court of India, in JUDGES AND THE JUDICIAL POWER: ESSAYS IN HONOUR OF JUSTICE V.R. KRISHNA IYER 294 (Rajeev Dhavan et al. eds., 1985).

157. Initial changes to standing occurred in the waning days of the Court's passive first period, in late 1976. In Maharaj Singh v. State of Uttar Pradesh, the Court held that "Locus standi' has a larger ambit in current legal semantics than the accepted, individualistic jurisprudence of old." A.I.R. 1976 S.C. 2602, 2609. See generally Baxi, supra note 156.

158. The founding of the People's Union for Civil Liberties (PUCL) in the midst of the emergency was a watershed moment in this movement. See People's Union for Civil Liberties, http://www.pucl.org/history.htm (last visited Nov. 5, 2005).

159. Maharaj Singh v. Uttar Pradesh, 1977 S.C.R. (1) 1072, 1082 (1976). 
foreign sources, including law review articles from the United States ${ }^{160}$ that argued for broadening standing in American jurisprudence (rather than providing actual case law), a Privy Council case involving The Gambia, ${ }^{16 !}$ and two century-old English cases ${ }^{162}$ in stating its revolutionary holding that any member of the public can maintain an application for relief.

Additionally, the courts became much more flexible in accepting pleas, with "reports of actions begun by postcard, and even of one judge converting a letter to the editor in a newspaper into a [public interest] ... writ." 163 Further, though the Indian courts' remedies were theoretically limited to the typical habeas corpus, mandamus, prohibition, quo warranto, and certiorari, the courts "have insisted on a flexible interpretation of their inherent power to do justice." 164

Almost all of the major cases during this period relied heavily on foreign precedent, invoking non-municipal law to legitimate liberties as varied as the right to a fair trial and freedoms of expression. Additionally, the Court also used foreign legal theories expressed by academics and commentators as a tool to support its activism. ${ }^{165}$

\section{i. Right to Life and Liberty}

The Court's 1977 decision in Maneka Gandhi v. Union of India ${ }^{166}$ was the critical inflexion point in the Court's movement toward judicial activism and away from parliamentary-imposed passivism. The case concerned the right to travel; a right that the Court held was constitutionally-mandated, even though it was not a specifically named fundamental right. Piecing together jurisprudence from the United States (in particular, Kent v. Dulles, 357 U.S. 116 (1958), and Aptheker v. Secretary of State, 378 U.S. 500 (1964), both of which found the right to travel "fundamental"), England, the UDHR, the European Court of Human Rights, and Blackstone's theory of natural law, the Court both found the existence this right and carved out a significant substantive due process protection within Article 21. Claiming that fundamental rights "weave together

160. Comment, Consumer Law-Standing-School Children Denied Standing to Sue for False Advertising Under Section 43(a) of the Lanham Act: Colligan v. Activities Club of New York (2d Cir. 1971), 46 N.Y.U. L. Rev. 807 (1971); Robert D. Van Home, Citizen Organizations Intervening in Federal Administrative Proceedings: The Lingering Issue of Standing, 51 B.U. L. Rev. 403 (1971).

161. Attorney-General of the Gambia v. N'Jie, [1961] A.C. 617, 634 (appeal taken from West African Court of Appeal).

162. Richardson v. Robertson, (1862) 6 L.T. 75; Hiride v. Chorlton, (1866) 2 C.P. 104, 116.

163. Jamie Cassels, Judicial Activism and Public Interest Litigation in India: Attempting the Impossible?, 37 AM. J. COMP. L. 495, 499 (1989).

164. See Cassels, supra note 164 , at 505 (referencing Bandua Mukti Morcha v. Union of India, A.I.R. 1984 S.C. 802).

165. Unfortunately, the increasingly progressive jurisprudence during this period was not always matched by robust implementation of judicial orders. It would be another decade before implementation of many progressive rulings would be assured.

166. A.I.R. 1978 S.C. 597. 
a pattern of human rights guarantees," 167 the Court held that any act violating Article 21 must meet the additional tests of anti-arbitrariness and reasonableness, as contained in Article 14 and the fundamental freedoms clause. Such an act cannot be "arbitrary, fanciful or oppressive."168 In the Court's view, Article 21 covered both implicit and explicit rights, and consequently "liberty" could not simply mean mere freedom from physical restraint. Rather, the term included a variety of ancillary rights critical to the full realization of an individual's personality, such as freedom to travel abroad.

\section{ii. Right to a Fair Trial}

After Maneka Gandhi, the Court moved to guarantee fair procedure and equal protection in criminal justice. The Court forged justiciable rights to free legal services, a speedy trial, and humane prison conditions. Again, foreign jurisprudence was a critical component of the Court's jurisprudence. In Hoskot v. State of Maharashtra, the Court referred explicitly to American jurisprudence, extolling that "Gideon's trumpet has been heard across the Atlantic" in asserting its holding that free legal services must be provided for the indigent. ${ }^{169}$ Substantive due process was implicated again in the Court's holding that free legal services were an "imperative processual piece of criminal justice" implicit in Article 21. Three years later, in Khatri v. State of Bihar, the Court solidified these protections, finding that the "law does not permit any government to deprive its citizens of constitutional rights on the plea of [the state's] poverty," a finding that also relied on foreign precedent. ${ }^{170}$

Sunil Batra v. Delhi Administration II set the trend for the development of jurisprudence requiring humane prison conditions, relying in large part on American academic Edward Corwin's theories of "cruel and unusual punishment" and a British parliamentary white paper entitled "People in Prison."171 To make prisoners' rights viable, the Court directed the district magistrates concerned to inspect the prisons in their jurisdictions once a week, to receive complaints from individual prisoners, to take remedial actions where they were deemed necessary, and to provide a grievance box to which all prisoners were to be given free access. The Court directed judicial officers to provide all prisoners a hearing complying with the principles of natural justice before revoking any benefit available to them. These were all strategies that had been employed in the U.S. and/or England.

167. A.I.R. 1978 S.C. $597,668$.

168. Id. at 674 .

169. A.I.R. 1978 S.C. 1548, 1554. The Hoskot court was referencing the U.S. Supreme Court case mandating legal aid for the poor, and the book on the subject by Anthony Lewis. See ANTHONY LEWIS, GIDEON'S TRUMPET (1964); Gideon v. Wainwright, 372 U.S. 335 (1963). 1974)).

170. A.I.R. 1981 S.C. 928, 931 (citing Rhem v. Malcolm, 371 F. Supp. 594 (S.D.N.Y.

171. A.I.R. 1980 S.C. $1579,1582-83$. The case also relied on several American law review articles, and United States Appellate and Supreme Court judgments. 
In Khatoon (IV) v. Home Secretary, State of Bihar, ${ }^{172}$ the Court maintained the pressure on reform it began in Sunil Batra, mandating the release of prisoners who had been incarcerated while awaiting trial for a period in excess of the maximum sentence possible for their alleged crime. In so doing, the Court reinforced substantive due process guarantees holding that the law must consist of "reasonable, fair and just procedure."173 The Court mandated improvements in the prison system, using the example of the "courts in the United States." ${ }^{174}$ Citing several American lower court cases, ${ }^{175}$ the Indian Supreme Court argued that their American counterparts have used the "activist magnitude of the Eight Amendment" and "adopted this dynamic ... role so far as ... prison reform is concerned ..., order[ing] substantial improvements ... in a variety of archaic prisons." 176

\section{iii. Right to Free Expression}

The other individual right that had been abused during the Emergency, and was thus ripe for redress, was the right of free expression. In this realm, the Court also moved in line with Western and emerging international standards to provide constitutional guarantees for such expression. In Indian Express Newspapers $v$. Union of India, ${ }^{177}$ referring to substantial amounts of American precedent, (including The Federalist Papers and the U.S. Constitution), the Privy Council, and various international declarations, the Court held that the imposition of a tax on the publication of newspapers violated the constitutional right to freedom of expression, which incorporates freedom of the press. ${ }^{178} \mathrm{In}$ Rangarajan v. Jagjivan Ram \& Ors and Union of India, ${ }^{179}$ the Court found that the censoring of a film critical of government policy was inconsistent with the principle of freedom of expression, again relying heavily on American case law (particularly Schenck v. United States, 249 U.S. 47 (1919), and its progeny) and English precedent.

\section{1992-Present: The Era of Globalization and the Rise of "Second Order" Rights}

National instability was exacerbated in the 1990 s with the increase in internal and external terror attacks, political assassinations, sectarian violence,

172. 1979 S.C.R. (3) 532.

173. Id. at 537.

174. Id. at 543 .

175. Interestingly, the court focused on citing cases from the lowest U.S. federal courts, such as Rhem v. Malcolm, 371 F. Supp. 594 (S.D.N.Y. 1974), Newman v. Alabama, 349 F. Supp. 278 (M.D. Ala. 1972), and Gates v. Collier, 349 F. Supp. 881 (N.D. Miss. 1972).

176. 1979 S.C.R. (3) $532,543$.

177. A.I.R. 1986 S.C. 515.

178. The Court referred, inter alia, to several law review articles on the First Amendment, The Federalist No. 84, the UNESCO Declaration on the Mass Media, UDHR Article 19, ICCPR Article 19, ECHR Article 10, and more than a dozen American and Privy Council cases.

179. (1989) 2 S.C.C. 574. 
and international tensions. ${ }^{180}$ In contrast to the relative political constancy of previous decades, the 1990 s witnessed a rapid turnover of central governments, with four general elections between 1996 and 1999 alone (in the forty-four years prior to 1991, there had only been ten general elections). Added to this political instability were vast changes in the social and economic fabric of the country following the end of the planned economy and the start of liberalization. This led to wide fluctuations in prosperity and severe exacerbations of inequality.

Compared to the fluctuations of politics and economics around it, the Court's stability was remarkable. During the initial period of liberalization, the Court managed not only to maintain its powers but also enhance them, "forcing the government's hand" on many occasions. ${ }^{181}$ The 1990s saw the Court adopt both administrative and policy-making roles, with its jurisprudence placing a growing emphasis on implementation of judgments and keeping governmental compliance under perennial judicial review. This "review" has ranged from requesting periodic reports on implementation of orders, ${ }^{182}$ to the Court's explicit assumption of governmental enforcement and policy-making functions. ${ }^{183}$ The focus on implementation has been one of the key features of the Court's decisions since the 1990 s, and has played a critical role in the Court's ability to expand the protections of rights even further.

The non-governmental organization sector, which boomed in the wake of the Court's enhancement of standing rights, has helped shape much recent jurisprudence. The trend of NGOs taking on essentially legislative duties-a process that has further empowered the bench-has led the Court to adopt the voluntary sector's views on many issues. For instance, since the early 1990s, one of the key goals of the NGO movement has been to moderate the impact of globalization on India. In so doing, they and the Court have moved passed the provision of individual, "first order" civil and political rights, and begun to militate for broader "second-order" rights related to sustainable development, the maintenance of public trust, and the securing of intra-generational equity. The Court's complicity in this project has led to a retreat on some individual rights, see infra Part VI, and a clear expansion of the reliance on international covenants and agreements (rather than foreign domestic precedents) in its judgments. This reliance is not surprising given that many major constitutional states do not fully provide for such second-order rights, ${ }^{184}$ while the

180. The early 1990s alone saw the expansion of Islamic terrorism in Kashmir, the formation of a militant group fighting for secession in Tripura, the rise and crushing of Sikh strongholds in Punjab, the assassination of Rajiv Gandhi by Tamil separatists, the destruction of the Ayodhya mosque and resultant Hindu-Muslim rioting and violence, and the bombing of the Bombay stock exchange.

181. See Thakur, supra note 103.

182. Bandua Mukti Morcha v. Union of India, A.I.R. 1984 S.C. 802.

183. In 1998, in the state of Uttar Pradesh, the "Supreme Court assumed the functions of the governor in summoning the Assembly, the speaker in setting the agenda, and the Assembly itself directing that a vote be held on specific legislation." See Thakur, supra note 103, at 622 .

184. Sunstein notes that providing for such rights is a unique characteristic of post-1989 constitutions. See Sunstein, supra note 92. 
international community has been in the vanguard of such provisions.

Two broad sets of "second-order" rights secured by the Court-at the urging of the NGO community-during this period have been related to the environment and good governance. ${ }^{185}$ The reliance on international covenants as support for the Court's reasoning is notable.

\section{i. Environmental Jurisprudence}

The Court's move toward environmental jurisprudence, and the consequent enforcement of its decisions by the executive, represented a sea change in the political economy of India and a new confidence in the ability of the state to provide both for development and sustainable living conditions. Historically, all environmental regulations had been subordinated to economic growth, with no comprehensive environmental legislation enacted until $1986 .^{186}$

The Court's leadership of the "green" movement was aided by the body's early 1990s jurisprudence, which suggested that the right to an environment was fundamentally bound up in the provision of other first- and second-order rights.

185. These two rights are examples of a large number that the Court has secured since the early 1990s — other "second order" rights protected during this period include the right to work, the right to shelter, the right to health, the right to development, the right to education, and a broad right to privacy. Again, in almost all cases, international agreements were used to buttress the Court's holdings. Regarding gender discrimination, in C. M. Mudadliar v. Idol of S.S.S. Thirukoil, (1996) 3 S.C.C. 525; Madhu Kishwar v. State of Bihar, (1996) 5 S.C.C. 125; and Vishaka v. State of Rajasthan, (1997) 6 S.C.C. 241, the Supreme Court voided all gender-based discrimination and condemned sexual harassment, and in so doing implicated CEDAW Articles 2(e) and 25 and the Declaration of the Right to Development Articles 1 and 6. In Chamenli Singh v. State of Uttar Pradesh, (1996) 2 S.C.C. 549, the Court provided for the right to shelter, referring to the UDHR, a document to which the Court also referred in providing a broad right to health. See CESC Ltd. v. Subhash Chadra Bose, (1992) 1 S.C.C. 441 (referring to UDHR Articles 22 and 25); Regional Director, ESI Corp. v. Francis De Costa, 1993 Supp. (4) S.C.C. 100 (referring to UDHR Article 25(2) and ICESCR Article 7(b)). The Court also furthered a number of other rights through resort to international covenants (ICCPR, CRC, UDHR and CEDAW). See Samatha v. State of Andrah Pradesh, (1997) 8 S.C.C. 191 (the right to development); Bandhua Mukti Morcha v. Union of India, (1997) 10 S.C.C. 549 (the right to development for children specifically); Mohini Jain v. State of Karnataka, (1992) 3 S.C.C. 666 (the right to education). The right to privacy-ensured via a Court order that phone tapping procedures need to be established by a law that is just, fair and reasonable, in line with ICCPR guarantees-was established in People's Union for Civil Liberties v. Union of India, (1997) 3 S.C.C. 301. Some second order rights were provided at the very end of the prior period, such as the right to a livelihood, secured through Olga Tellis v. Bombay Municipal Corporation, 1985 (3) S.C.C. 545. For a partial compilation of this list of cases, see Nishant Singh, National Application of International Legal Norms: Analysing Fifty Years of Indian Experience (unpublished paper, on file with author).

186. Ananyo Basu, Torts in India: Dharmic Resignation, Colonial Subjugation, or 'Underdevelopment'?, 100 S. ATL. Q. 1053 (2001). However, the Court's first substantial word on the subject actually came a year prior in Rural Litigation \& Entitlement Kendra, Dehradun v. State of Uttar Pradesh, 1987 S.C.R. (1)641, one of the first environmental complaints it ever addressed. Signaling the direction it would be moving, the Court held in Dehradun:

Preservation of the environment and keeping the ecological balance unaffected is a task which not only Governments but also every citizen must undertake. It is a social obligation and every Indian citizen is reminded that it is his fundamental duty as enshrined in Article $51 \mathrm{~A}(\mathrm{~g})$ of the Constitution.

1987 S.C.R. (1) $641,643-44$. 
Finding the "right to life" supported not just by Article 21 of the Indian Constitution, but also Article 6 of the ICCPR and Article 3 of the UDHR, the Court held that this right included the right to an adequate means of subsistence and a decent standard of life. "From this perspective, the right to a healthy and ... wholesome environment appear[ed] . . . a natural corollary of the right to life." 187

In a string of decisions that referred to multilateral materials as varied as international treaties and travawx préparatoires of conferences, the Court markedly expanded the right to a "healthy environment." In Subhash Kumar v. State of Bihar, the Court held that a slow, steady, and subtle method of extinguishment ${ }^{188}$-via severe pollution-was violative of the right to life and in Virender Gaur v. State of Haryana, ${ }^{189}$ the Supreme Court reiterated that Article 21 includes a right to a clean environment. The Court invoked U.N. proclamations - not law-in two of the most substantial environmental cases that it has faced thus far. First, M.C. Mehta $v$. Union of India saw the Court dwell at length on the famous proclamation adopted at the 1972 U.N. Stockholm Conference on Human Environment. ${ }^{190}$ Then, in Law Society of India $v$. Fertilizers and Chemicals Travancore, the Court relied on a 1984 U.N. Resolution holding that an environment adequate for health and well-being was a fundamental right to reiterate that the right to a wholesome environment was implicit in Article 21. 191

\section{ii. Good Governance}

The Court's work on wider social and cultural rights, combined with its focus on implementation, led to the Court's embarking on an ambitious program designed to ensure good governance. In so doing, the Court was expansive in its orders and again heavily reliant on foreign precedent. In Vineet Narain $v$. Union of India, the Court explicated seven principles of public life, and ordered the establishment of an institution akin to the English "Director of Prosecutions" to investigate governmental wrongdoing. ${ }^{192}$ In People's Union for Civil Liberties v. Union of India ${ }^{193}$ and Association for Democratic Reforms $v$. Union of India, ${ }^{194}$ the Court mandated increased transparency in electoral systems and provided for a broad right to information under the theory that such compelled disclosure would ensure good behavior on behalf of the government. In its

187. Sripati, supra note 87 , at 112 .

188. A.I.R. 1991 S.C. $420,424$.

189. 1995 (2) S.C.C. 577.

190. 1988 S.C.R. (2) 530 (1987), available at http//judis.nic.in/supremecourt/qry disp.asp?tfnm $=8590$, at 285 .

191. A.I.R. 1994 Ker. 308.

192. A.I.R. 1998 S.C. 889.

193. A.I.R. 1997 S.C. 568. See also PUCL Bulletin, Landmark Supreme Court Judgment: For Cleaner Elections (June 2002), http://www.pucl.org/Topics/Law/2002/elections.htm (last visited May 2, 2005).

194. Civil Writ Petition \# 7257 (1999) (Delhi H.C.). 
observations and judgments, the Court cited both the Beijing Statement of Principles of the Independence of the Judiciary and the ICCPR.

Starting in 1993, the Supreme Court even directed attention to its own operations, and took measures to bolster the integrity of the courts and protect civil liberties in the face of state coercion. In an effort to avoid the appearance of conflict of interest in the judiciary, Chief Justice Venkatachaliah initiated a controversial model code of conduct for judges that required the transfer of high court judges who had children practicing as attorneys in their courts, ${ }^{195}$ and in 1996, the Court launched a massive bribery investigation involving dozens of politicians from across the political spectrum. ${ }^{196}$

VI.

\section{FOREIGN LAW AND THE EXPANSION OF RIGHTS}

The preceding overview of the Indian Supreme Court's avoidance of foreign law in the early stages of the republic, subsequent reliance on foreign, domestic precedents to buttress first-order, individual political and civic rights, and later reliance on international law to expand second-order, social and cultural rights, provides a clear picture of an instrumental reliance by the Court on non-domestic precedent. This trend has only intensified since the 1990s as the Indian Court has amassed more power and the country has undergone significant changes through its immersion in globalization.

Figure $\mathrm{V}$ provides some additional support for these conclusions. By mapping the use of foreign law in Indian Supreme Court judgments against the rise and fall of civil and political rights in the country-as measured by Freedom House ${ }^{197}$ - the relationship between rights and foreign law becomes even clearer, especially in more recent Supreme Court jurisprudence.

195. The Indian Supreme Court, http://www.indianchild.com/judicial_system_india.htm (last visited Apr. 30, 2005).

196. India: A System Shakes, THE ECONOMIST (American version), Mar. 23, 1996, at 35.

197. Freedom House data has been compiled annually since 1972 , with the organization analyzing two types of freedom (civil and political rights) on a scale of 1 (the most expansive) to 7 (the most restrictive). For further information on the process of constructing this measure, see Freedom House, at http://www.freedomhouse.org. Note, in order to map Freedom House ratings on the same graph as foreign law citations, I inverted the organization's measure, so that 7 now represents the most expansive in both categories of freedoms. 
Figure $\mathbf{V}$

India: Political and Civil Liberties Compared with \% Foreign Law Citations

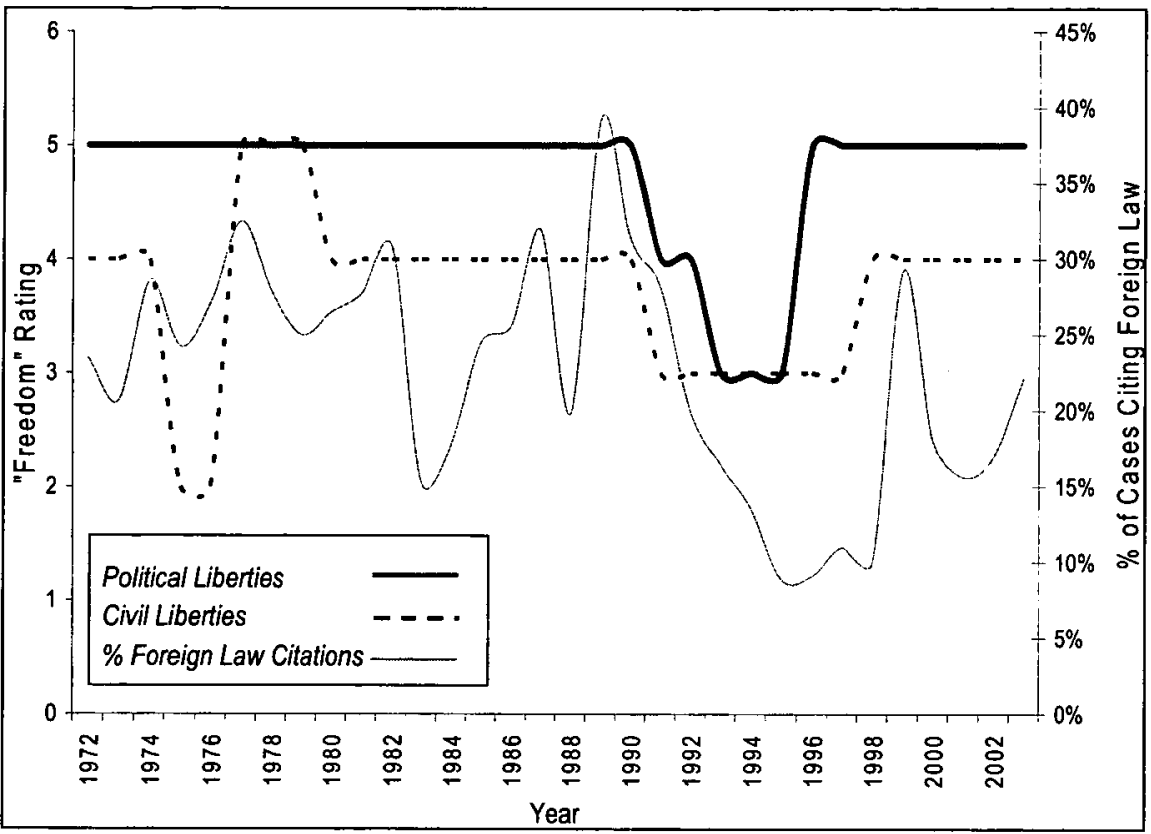

Despite the shallow rise of foreign law during the period from 1992 to the present, Figure $\mathrm{V}$ shows an abrupt decline of foreign law citations during the early 1990 s, followed by a marked increase in foreign law usage toward the end of the decade. The symmetry that this fluctuation has with civil/political rights during the same period is striking, especially when compared with the difficulty of ascertaining any relationship between foreign law and civil/political rights in the period prior to the 1990s.

The absence of a correlation leading up to the 1990 s, followed by the clear linkage between civil/political rights and foreign law, is another manifestation of the three periods of Indian legal history described above. The three periods are clearly present in Figure $\mathrm{V}$, with the contraposition of rights and foreign law shedding light on the real powers the Court had in each period. Prior to 1977, the Court was de facto and de jure impotent in the face of Congress Party supremacy; no matter the law cited, the expansion or suppression of civil/political rights was primarily a function of parliamentary or executive fiat rather than legal actions. Following the Emergency in 1977 and until the 1990s, the Court gained substantial de jure powers and, as argued above, managed to substantially expand the personal rights of Indians. However, the de jure 
powers during this period were not necessarily matched by de facto powers, with implementation of decisions lagging far behind the progressiveness of the jurisprudence. ${ }^{198}$ The plight of India's undertrials ${ }^{199}$ and the bleak situation regarding legal aid to the indigent ${ }^{200}$ are two prominent examples of this disjuncture between jurisprudence and implementation. It was only starting in the 1990s, when enforcement of Supreme Court writs became much more forceful, that the close relationship between the use of foreign law (itself closely related to the expansion or decline of civil and political rights) and actual freedoms began to cohere.

The simultaneous decline in rights and the use of foreign law in the early 1990 s reflects two fundamental trends in India. First, it suggests that with the 1990s' jurisprudential focus on globalization and second-order community rights (such as environmental protection), individual rights became more narrowly drawn. This may provide evidence for those who claim that individual rights and communal rights are, to a degree, mutually incompatible. ${ }^{201}$ Secondly, the tumult of the 1990s--unprecedented, even in comparison to the violent fluctuations of India's post-Independence history-led to governmental encroachment on individual rights in many areas of India (especially at the state level), in an effort to reassert order. Indian legal elites have long been concerned about the balance between political stability and individual rights, with the former regularly trumping the latter. During the Indian Constitutional Convention, this inherent conservatism led to the removal of due process protections in the wake of Gandhi's assassination and the instability of Partition.

198. See generally S. Muralidhar, Implementation of Court Orders in the Area of Economic, Social and Cultural Rights: An Overview of the Experience of the Indian Judiciary (IELRC Working Paper 2002-2), available at http://www.ielrc.org/content/w0202.pdf. Historically, there has been widespread disregard for court orders. See, e.g., M.L. Sachdev v. Union of India, A.I.R. 1991 S.C. 311; All India Judges' Association v. Union of India, 1995 (2) S.C.A.L.E. 374.

199. The plight of India's "undertrials"-those individuals awaiting trial in prison, though often not charged -and the provision of legal aid are the most potent examples of this disjuncture between jurisprudence and actual changes on the ground. In the days after the emergency, the Hussainara cases (see above) called for a reformation of the system under which bail was almost never granted, demanded that courts become involved if a non-charged suspect is held for longer than fifteen days, and held that speedy trials were a constitutional right. Despite strong jurisprudence since then, the undertrial situation in India was arguably exacerbated. By the end of the 1980s, more than seventy percent of India's prisoners were "undertrials," a figure somewhat higher than the proportion recorded in the 1960s. See Prison Statistics 2000, 2002: India's Parliamentary Standing Committee on Home Affairs, in JAGMOHAN SINGH, RIGHT TO SPEEDY JUSTICE FOR UNDERTRIAL PRISONERS 277 (1997); 23rd Asia and Pacific Conference of Correctional Administrators, Appendix B: Correctional Statistics for Asia and the Pacific (2003), http://www.apcca.org/23rd\%20apcca\%20conference\%20report/23rdAPCCA/Conference_report.htm (last visited Nov. 6, 2005).

200. Despite successive decisions mandating legal assistance for the indigent, India has failed to provide "efficient and capable" support in this arena, a situation exacerbated by the government's ambivalent support for the legal aid project. Rajeev Dhavan, Law as Struggle: Public Interest Law in India, 36 J. IND. L. INST. 302, 325 (1994).

201. See generally D.M. Davis, The Case Against the Inclusion of Socio-Economic Demands in a Bill of Rights Except as Directive Principles, 8 S. AFR. J. HUM. RTS. 475 (1992); Nicholas Haysom, Constitutionalism, Majoritarian Democracy and Socio-Economic Rights, 8 S. AFR. J. HUM. RTS. 451 (1992). 
In the 1990s, judges were keenly aware of the terrors of religious extremism and separatism, ${ }^{202}$ and seemingly went along with the political elites in retreating on individual rights. ${ }^{203}$ As Figure $\mathrm{V}$ indicates, the Court's decline in usage of foreign law actually preceded the decline in civil and political rights in the early part of the 1990s. In the late 1990s, the Court's significant lag in increasing foreign law citations-in comparison with the actual increase in civil and political rights on the ground-illustrates that the Court was probably even more conservative than other branches of the government in its unwillingness, during the latter part of the decade, to accept the return of civil and political rights.

\section{VII.}

\section{THE INDIAN CASE AS AN EXPLICATOR FOR THE BROADER DEBATE}

Though there are aspects of the Indian experience which likely cannot translate to other states, ${ }^{204}$ there are at least three primary lessons that the Indian experience can teach both the proponents and opponents of foreign law usage in domestic jurisprudence. First, it has been argued that the Indian Supreme Court is one of the most powerful judiciaries in the world, ${ }^{205}$ serving as an explicit "arm of the social revolution" envisaged by India's constitutional framers. ${ }^{206}$ The weakness of the other political branches and the credibility the Court enjoys throughout the country have been significant factors in its ascendance, and the differential in power between the Supreme Court and other national entities is more extreme in India than most other states. Yet, despite its power, it is evident that the Court has nonetheless been as much a product of historical forces as a driver of those forces. Political, social, and economic events outside the Court have driven its members to take certain actions and refrain from others.

For instance, it seems evident that the wider political environment greatly impacts judicial views. The 1975 Shiva case upholding the suspension of habeas corpus during the Emergency received a four to one majority on the bench. However, two years later, in Maneka Gandhi, a case in which the right

202. See, e.g., CPI Wants Judicial Panel on Terrorism, THE HINDU, Sept. 26, 1997, at 9; Gill v. Imundi, 747 F. Supp. 1028 (S.D.N.Y. 1990) (litigating a high-profile Sikh terrorism case in the United States).

203. A key example of this retreat is the existence of the "President's Rule" in India's states, by which the state assembly is dismissed and Delhi is charged with direct governance of the territory. Although the President's Rule normally lasts for only six months - with the possibility of extension for up to one year with Parliamentary approval-the 1990s saw exceptional cases, such as in strife-torn Jammu and Kashmir, where such direct, non-democratic rule lasted for more than five years. The Supreme Court was complicit in this exercise of non-Democratic power.

204. For instance, it is difficult to determine how much influence particularly persuasive judges have in different national contexts. In the Indian case, there are judges who have been known for various proclivities (such as Justice Singh's interest in protecting the environment and Justice Bhagwati's desire to cite foreign law), but it is unknown what impact these personalities actually had on decisions, or what judges with similar "side interests" would do in other systems.

205. Some commentators have argued that the extent to which the Indian Supreme Court has managed to enhance its own autonomy may be unparalleled in the world. Moog, supra note 137.

206. See generally Austin, supra note 83 . 
to life under Article 21 was held to have the widest of possible meanings, two of the judges who had supported the government in Shiva now extended their votes to expand the rights of the appellant. In explaining his change of heart, Justice Bhagwati proclaimed that his vote in 1975 was compelled by the political exigencies of the time and his fear that the Court would be delegitimized: "The lady [Prime Minister Indira Gandhi] was too powerful.,"207

Thirty years later, the Court remains fundamentally aware of political realities and clearly makes decisions with them in mind. Most evident in this regard are the standing orders the Supreme Court issues to insure implementation of its judgments. It enforces its orders by reference to politically sensitive matters, threatening the arrest of offending ministers who refuse or fail to implement judgments, or, even more effectively, threatening their careers by ensuring via procedural methods that they will be passed up for promotion if they are not successful in implementation. ${ }^{208}$

Similar to their counterparts in India, many of the world's judiciaries are undergoing a revolution in empowerment, with ever greater competencies entrusted to the bench. Called by some the dawn of a "jurist-ocracy,"209 the power of the judiciary-especially in constitutional states that have granted judges wide judicial review ${ }^{210}$ - is significant and in many cases seemingly places the bench above the fray of quotidian politics. Yet, as the Indian case illustrates, the relationship between courts and political elites is fraught with complexities, primarily because the judiciary can simultaneously function to aid the other branches of government-by providing a legitimizing imprimatur on unpopular decisions (as it did during the Emergency) or threatening the elites by subsuming some of their powers-as the Court has done more recently by becoming active in the actual administration of its orders. 211

If the powerful Indian judiciary is buffeted by history and wider political forces, most other national judiciaries will also experience such impacts. This, in turn, renders the normative demands of both internationalists and isolationists untenable, at least to a degree. In most jurisdictions, the ability to use or ignore foreign law is not directly susceptible to a simple choice on the part of judges. Rather, the use or absence of foreign law in decisions is to greater or lesser degrees a function of wider pressures that judges and courts are often unable to fully control.

The second shared experience regards the selectivity involved in the use of

207. Though often-cited, there is no written evidence that Bhagwati ever actually said it.

208. For an example of a case in which the Court has demanded such continuous reports of implementation-on pain of contempt, see Bandua Mukit Morcha v. Union of India, A.I.R. 1984 S.C. 802.

209. RAN HIRSCHL, TOWARDS JURISTOCRACY: THE ORIGINS AND CONSEQUENCES OF THE NEW CONSTITUTIONALISM (2004).

210. This group of countries includes most of formerly communist Eastern Europe, South Africa, and Canada.

211. Robert Moog, Elite-Court Relations in India: An Unsatisfactory Arrangement, 38 ASIAN SURV. 410, 411 (1998). 
foreign law. In almost all cases, the Indian use of foreign law has occurred when two situations have arisen simultaneously: first, the Court wishes to expand certain rights provided by the state; and second, this expansion is substantial enough that there are insufficient domestic precedents and the Court would potentially sacrifice its legitimacy if it were to issue a judicial fiat without any supporting case law. Though there has been some reticence to rely on other countries' precedents in India, ${ }^{2} 2$ foreign law has become a common solution to this quandary. Logically, this would be all the more true for judges in countries which have recently established (or re-established) independent judiciaries, and/or countries in which the courts are not accorded sufficient institutional strength.

The selectivity with which courts use foreign law-and in many cases foreign law augmented by foreign "non-law," such as academic articles, theories, and political pronouncements-provides force to the isolationist critique regarding selectivity. This selectivity can be seen in India during the 1990s when the reduction in rights and use of foreign law in the early part of the decade was followed by an increase in both during the latter half of the decade. The selectivity of jurisprudence is evident from the fact that during the 1990s, global jurisprudence, as a whole, became more protective of individual rights (thanks in part to the end of Communism and the rise of democratic constitutionalism in many parts of the world), while the Indian Supreme Court clearly chose to ignore this trend in its individual rights jurisprudence for much of the decade. Yet once the Court became determined to press forward with individual rights, foreign law became an important part of the body's arsenal of precedents.

Additionally, since 1977, the Indian Court has been noticeably selective regarding what jurisdictions' laws it cites. In the 1980 s, as the Court sought to expand personal rights and liberties, the body relied heavily on American precedent, along with a healthy resort to English and Canadian cases. However, when the Court's focus changed to look at broader, secondary rights (the environment, health, etc.), it began to focus much more on international covenants and treaties. To some this might seem somewhat strange, given that by this time-and especially by the turn of the century-there were many domestic jurisdictions (South Africa, in particular ${ }^{213}$ ) that had developed significant case law regarding such rights. However, it seems that the Indian courts established a hierarchy of jurisdictions to which they wished to cite, and given that the American government and courts (as well as those in England and many other developed countries) had been "conspicuously reluctant to recognize

212. For instance, in Indian Express Newspapers $v$. Union of India, the court argued that "we cannot, no doubt, be solely guided by the decisions of the Supreme Court of the United States of America. But in order to understand the basic principles of freedom of speech and expression, and the need for that freedom in a democratic country, we may take them into consideration." A.I.R. 1986 S.C. 515,531 . Afr.).

213. See, e.g., Gov't of the Republic of S. Afr. v. Grootboom, 2000 (11) BCLR 1169 (CC) (S. 
economic and social rights, the international, rather than the domestic, realm. Such selectivity and hierarchy in the citation of different jurisdictions' precedents also is present in many other domestic judiciaries' use of non-municipal law.

While the selectivity of the Indian Court is perhaps extreme, it is important to note this selectivity was present throughout the decade, even at the ebb of foreign law usage and civil/political rights protection. During the decline of rights, the Supreme Court relied less on international law and more on the domestic jurisprudence that supported the reduction in rights. When the Court deemed it appropriate to expand the rights, it again found foreign law on which to base its new jurisprudence. At all times, the Court was selective in its use of case law, "cherry picking" those cases that most supported the direction in which it wanted to take India.

This relates to the third characteristic shared between the Indian case and the global community of constitutional courts which speaks to how foreign law is used. In India and elsewhere, foreign judgments are used aspirationally. Foreign law and precedent come into judgments in the form of culturally persuasive (even if not legally relevant) support for a change that coheres with the judges' views of the type of culture to which their state aspires. For instance, in the Indian legal services case Hoskot, see supra at VI.B.ii, the Indian Supreme Court Justices did not mention the holding in the American case Gideon v. Wainwright because it was binding on the Indian Court. Rather, they mentioned it to indicate a wider trend regarding defendants' rights that was sweeping the international, developed community-a community which Indians desperately wished to join. Such aspirations were even clearer in Khatoon (I) $v$. Home Secretary, State of Bihar, in which the Court found that the right to bail and, in particular, pre-trial release, must be provided to arrestees. ${ }^{215}$ In Justice Bhagwati's separate opinion, he argued that "the new insight into the subject of pretrial release which has been developed in socially advanced countries... should ... inform the decisions of our Courts."216

While usually less obvious than Bhagwati's statement, the aspirational process is also present in the foreign law usage of longstanding constitutional courts in developed states. Though Justice Kennedy did not need precedent from outside the United States supporting the legality of homosexual sodomy to write his opinion in Lawrence v. Texas, that the United States was so clearly out of step with those states to which it most readily compares itself provided another, culturally specific, (even if not legally relevant), argument. Moreover, Justice Kennedy's use of "global consensus" was in direct opposition to Justice Burger's similar aspirational reference to the world community (and in particular, the Judeo-Christian culture to which he thought America should

214. Jessica Schultz, Economic and Social Rights in the United States: An Overview of the Domestic Legal Framework, 11 HUM. RTS. BR. 1, 1 (2003).

215. 1979 S.C.R. (3) $169,170$.

216. Id. at 177 (emphasis added). 
ascribe) in the Bowers case that Lawrence explicitly overruled. ${ }^{217}$

This similarity between Indian and foreign cases also makes clear the complex dynamic at work in bringing foreign law into play in the domestic realm. A nuanced exchange between and among courts, culture, judges, and society is determinative of both whether foreign law is implicated, and if it is, what its reception will be.

VIII.

CONCLUSION: UNDERSTANDING AND REFRAMING THE AMERICAN AND GLOBAL DEBATES

While elements of the foreign law debate have long existed in both the United States and elsewhere, recent discussions of this topic have greatly intensified. Growing European legal amalgamation (and the reticence of some member states to continue moving toward an ever closer Union), the expanding reach of international law in both the private and public sectors, and the rise in debate amongst the lay public about issues of foreign law usage that had once been confined to the legal academy, has given a degree of urgency to the discussion.

Though the modern United States is not exceptional in regard to the existence of the debate (it has existed since the founding of the Republic and finds replications in many other states), America is unique in both the strength of the lobby urging against incorporation of foreign precedents and in the significant ability of American jurists to steer clear of non-municipal law if they choose to do so. The lobby, which is clearly ascendant, comes from a powerful position, not only due to its alliance with the powerful conservative movement in the country, but also because of the "separatist" history of the United States. In many respects, the American Revolution and the legal system it spawned are defined as a rejection of the particular modes of tradition and historical interpretation prevailing in Europe. ${ }^{218}$ Justice Scalia's hostility to foreign law, ${ }^{219}$ and the extreme, but seriously respected suggestion that the implicating of foreign law by U.S. courts erodes American sovereignty, ${ }^{220}$ stem from the

217. See Lawrence, 539 U.S. 558 (2003); Bowers v. Hardwick, 478 U.S. 186, 197 (1986) (Burger, J., concurring).

218. For example, the Declaration of Independence explains the rationale for war against England as based on the King subjecting the colonialists to "a jurisdiction foreign to [their] Constitution, and unacknowledged by [their] laws." THE DECLARATION OF INDEPENDENCE para. 2, cl. 14 (U.S. 1776). See also Remarks of Congressman Tom Feeney, On the Hearing on the Courts and International Law Subcommittee on the Constitution, March 25, 2004, http://www.house.gov/feeney/downloads/reaffirm/tfstatementmarkup5-13-4.pdf (last visited Nov. 6, 2005).

219. See, e.g., Scalia, supra note 22.

220. See, e.g., Eric Hargan, The Sovereignty Implications of Two Recent Supreme Court Decisions, The Federalist Society of Law and Public Policy Studies, htip://www.fedsoc.org/Intllaw\&\%20AmerSov/hargensov.pdf (last visited Nov. 5, 2005). Hargan argues that citations to foreign law are not only alien to the American legal system, but if unchecked, "will produce a further erosion of American sovereignty, in addition to the mischief already done by these 
notion that using foreign law somehow reverts the United States to a position of pre-Revolution subservience. This, in turn, plays a defining role in the popular psyche, driving a large proportion of Americans to similarly look askance at the use of foreign law. 21

As a result of this tradition, though foreign law has always played some role in American jurisprudence, not only has there historically been little teaching of foreign law in American law schools, ${ }^{222}$ but significant judicial decisions have regularly abjured the use of non-municipal precedent. With a few notable exceptions, ${ }^{223}$ a cataloging of the major U.S. Supreme Court cases that helped forge core rights as varied as free speech, ${ }^{224}$ fair trial, ${ }^{225}$ freedom of religion, ${ }^{226}$ and broader civil rights ${ }^{227}$ are bereft of foreign references. Moreover, the U.S. is somewhat unique in both the size of its populace, the availability and sophistication of its courts, and the ever greater ease of reference to other American court decisions, all of which allow American justices to maintain their self-referential ways.

However, based on the Indian case, this essay suggests that such an isolationist approach will be difficult to maintain. Despite the irresolute use of foreign law by even the internationalists' strongest supporters, ${ }^{228}$ the difficulty

cases." Id. See also H.R. Res. 568, supra note 4.

221. The breadth of support for the "isolationist" school is illustrated both by the increasing public comment and concern regarding this issue (in various editorials and publications) and the fact that Representative Feeney's House Resolution 97 (expressing the House of Representative's sense that U.S. courts' citation to foreign law is detrimental to American governance) has 74 co-sponsors. Congressman Tom Feeney, Sponsored and Co-sponsored Legislation, http://www.house.gov/feeney/reaffirmation.htm (last visited Nov. 16, 2005); H.R. 97, 109th Cong. (2005) (formerly H.R. 568, approved by the Const. Subcommittee in 108th Cong. (May 13, 2005)).

222. Alain Levasseur, Use of Comparative Law by Courts (II), 42 AM. J. COMP. L. 41, 41-42 (Supp. 1994).

223. Such exceptions are often in the realm of "moral" issues and determinations of "reasonableness," instances in which some members of the Court have long thought foreign views on the subject were relevant. Atkins, Lawrence, and Roper are three of the latest in a line of such decisions, which include Roe v. Wade, 410 U.S. 113, 130-38 (1973) (protecting abortion); Miranda v. Arizona, 384 U.S. 436, 447-48, 486-90 (1966) (mandating that arrestees be informed of their rights before interrogation); Reynolds v. United States, 98 U.S. 145, 154, 158, 164-67 (1879) (banning polygamy); and Palko v. Connecticut, 302 U.S. 319, 326 (1937) (ruling that a right to a grand jury is not "fundamental"). Critics of foreign law note that foreign citations have also been used to justify evils such as slavery and resulted in decisions that have been thoroughly repudiated. See, e.g., Dred Scott v. Sandford, 60 U.S. 393, 407-09 (1897); Lochner v. New York, 198 U.S. 45, 51 (1905) (holding that a state-mandated limit on the work hours could not be enforced); Adamson v. California, 332 U.S. 46, 63 (1947) (ruling that a prosecutor could comment on a defendant's failure to testify at trial).

224. See, e.g., Texas v. Johnson, 491 U.S. 397 (1989); New York Times v. Sullivan, 376 U.S. 254 (1964).

225. See, e.g., Gideon v. Wainwright, 372 U.S. 335 (1963).

226. See, e.g., Engel v. Vitale, 370 U.S. 421 (1962); Abington v. Schemp, 374 U.S. 203 (1963).

227. See, e.g., Brown v. Bd. of Educ., 347 U.S. 483 (1954).

228. Raalf argues that even in the decisions of the staunchest internationalists, the use of foreign law remains tentative, "more properly described as a 'polite reference,' rather than persuasive authority." Matthew Raalf, $A$ Sheep in Wolf's Clothing: Why the Debate Surrounding Comparative Constitutional Law is Spectacularly Ordinary, 73 FORDHAM L. REV. 1239, 1241 
of internationalizing the American system, ${ }^{229}$ and the current political power of the conservative right that, inter alia, demands the impeachment of judges who cite foreign precedents, ${ }^{230}$ the internationalization of the American judiciary seems inevitable. The reasons for this inevitability rest on two particularly American factors and on two factors that the American system shares with most others and that are clear in the Indian case. Regarding the former, it appears as though the isolationists have few champions on the bench, and in particular on the Supreme Court. Though the isolationist school in America has primarily been supported by the conservative right, jurists who have recently come under fire for decisions that cite foreign law include Justices Kennedy, O'Connor, and Rehnquist, ${ }^{231}$ all whom were appointed for their supposed conservative credentials. 232

Even the isolationists' most identified supporter is not indefatigable. Though Justice Scalia's forceful statements against the use of foreign law are regularly cited by isolationists, his not infrequent citation to, and approval of, foreign law ought to be less comforting. In the recent Small v. United States, 233 the Court was asked if the foreign conviction of an American citizen should be regarded as a conviction by the U.S. In a reversal of usual positions, Justice Breyer argued that, given the questionable law of some foreign jurisdictions, such judgments should not count. Justice Scalia, however, railed against this position, arguing that the conviction rendered by a foreign state needs to be recognized as a genuine legal infraction. Though importing convictions from overseas courts is distinct from importing judicial philosophy, doing either seems somewhat inconsistent if one follows Scalia's philosophy that the unique moral and legal framework of the United States makes "foreign law ... irrelevant" 234 and that "[acknowledgement of] foreign [legal] approval has no

(2004). This reticence regularly translates into only superficial use of foreign law. For instance, instead of dissecting the reasoning of foreign courts, the Court treats the existence of international norms "merely as empirically observable facts rather than expressions of considered judgments." Id. Further, justices have also explicitly noted in their decisions that comparative materials have little bearing and, though useful, are not binding. See, e.g., Knight v. Florida, 528 U.S. 990, 998 (Breyer, J., dissenting). See also Louis J. Blum, Mixed Signals: The Limited Role of Comparative Analysis in Constitutional Adjudication, 39 SAN DIEGo L. REV. 157, 162 (2002).

229. For a recent discussion of some of the difficulties of directly borrowing foreign law in the American context, see Oscar Chase, American "Exceptionalism" and Comparative Procedure, 50 AM. J. COMP. L. 277 (2002).

230. See supra note 4.

231. Chief Justice Rehnquist used comparative law in the 1997 cases Washington $v$. Glucksburg, 521 U.S. 702, 794 (1997) (relying, in part, on the Dutch experience to reject the right to assisted suicide), and Raines v. Byrd, 521 U.S. 811,830 (1997) (bringing European constitutional decisions to bear on a question of American federalism). Rehnquist also expressed his support for increased resort to foreign law in a speech he gave in 1989. See William Rehnquist, Constitutional Courts-Comparative Remarks, in GERMANY AND ITS BASIC LAW: PAST, PRESENT AND FUTURE-A GERMAN-AMERICAN SYMPOSIUM 41 1, 412 (Paul Kirchhof \& Donald P. Kommers eds., 1993).

232. Justices Kennedy and $O^{\prime}$ Connor were appointed by President Reagan, while Justice Rehnquist was appointed by President Nixon.

233. Small v. United States, 125 S. Ct. 1752 (2005).

234. Scalia/Breyer Debate, supra note 5. 
place in the ... Court., 235

Secondly, the distinct makeup of American federalism suggests both a reason American judges have avoided foreign law and a rationale why U.S. jurists will come to increasingly rely on foreign precedent. The U.S. was founded as a weak federation of sovereign states, each maintaining extensive powers. ${ }^{236}$ Key among these prerogatives is the maintenance of significant legal independence, which led to the development of different bodies of law in each state. Initially, states viewed one another's laws with suspicion, but the growth of interstate commerce and the rising power of the federal government forced this bias to dissipate. ${ }^{237}$ As a result, modern state courts regularly cite the law of sister states. The existence of this body of comparative law within the United States has allowed American jurists the unique ability to be comparative without leaving the country. This phenomenon is one explanation why American judges have found it unnecessary to venture abroad for comparative precedents. Yet the same economic and political forces that compelled the states to respect one another's precedents are currently working on the United States and its "sister states" in the international arena. As international connections increase, transnational judicial disputes proliferate, and the need for the certainty of "global legal solutions" becomes apparent, it seems that the national state will have little choice but to follow the tradition established at the sub-national level and begin resorting to foreign law.

The pan-global rationale for the mounting internationalization of domestic judiciaries relates to the malleability of the distinction between the domestic and the foreign, and to the increasing limits on judges to not use foreign law, even if they wished to avoid doing so. Though public international law-via the International Criminal Court and the International Court of Justice-may remain fractured, ${ }^{238}$ with both powerful and weak states able to assert their independence from the system without severe consequence, the same cannot be said of private international law. In the private law context, states have little choice but to accede to jurisdiction, facing severe financial risks if they choose to reject private international law; to do so essentially would be to opt for financial isolation. ${ }^{239}$ The growth of cross-border legal proceedings, international, non-state arbitration, and the proliferation of new legal concepts that, due to international connections, demand similar definition across legal

235. Roper v. Simmons, 125 S. Ct. 1183, 1229 (2005) (Scalia, J., dissenting).

236. See, e.g., U.S. CONST, amend. 10.

237. States have come to believe Justice Brandeis's view that the benefits of federalism include the possibility that each state could be a laboratory for law (with states being able to learn from one another), New State Ice Co. v. Liebmann, 285 U.S. 262, 311 (1932) (Brandeis, J., dissenting), and Justice Cardozo's argument that the U.S. is "not so provincial as to say that every solution of a problem is wrong because we deal with it otherwise at home," Loucks v. Standard Oil Co., 120 N.E. 198, 201 (1918).

238. This may explain why comparativists have traditionally focused on private rather than public international law. Harding, supra note 67 , at 410.

239. Adam M. Smith, 'Judicial Nationalism' in International Law: National Identity and Judicial Autonomy at the ICJ, 40 TEX. INT'L L.J. 197, 228 (2005). 
systems, ${ }^{240}$ will forcefully bring the world into the domestic realm and viceversa. As this process continues, the difficulty of separating foreign from domestic will only increase.

This process will mean that even states that have attempted to foreswear foreign legal entanglements will become further enmeshed in them. Not only will this further dissolve the line between foreign and domestic, but it will import into domestic realms a new, international constituency. This trend will reinforce the internationalization and, in some senses, the homogenization of the global judiciary. Judges throughout the world are already growing more alike and "[the] growth of an international legal ethic and the creation of a larger, increasingly homogenous epistemic community of international jurists suggests that any local conception is quickly becoming internationalized." 241 The flocking of international law students to American centers of legal education, ${ }^{242}$ the posited Strasbourg Effect, ${ }^{243}$ by which trans-Atlantic jurists are coming to reason in the same manner, and the wider collegial and intellectual intermingling among the world's jurists (via "transjudicial communication"244 and other methods) are potent examples of this trend. Moreover, as a judge's constituency internationalizes, so too does a judge's audience. As judges increasingly make rulings that they know will not only be read by foreign jurists but also may have extra-territorial effects, they may feel compelled to justify their decisions to those outside their country. Reference to foreign law-either to laws of the specific states impacted by a ruling or to a putative "global consensus"-has already become a common method, and will likely grow in prevalence.

Despite this process, the future of international domestic law is not necessarily a positivist world of uniform, legal homogeneity. The Indian case and others suggest that we are unlikely to see a new age of ius commune. ${ }^{245}$ Too many distinctions remain, and the use of foreign law can work in both differentiating and harmonizing ways. Most simply, reference to international precedents can be used in order to explain a decision by a national court that fails to follow other states. The Canadian Court's explicit decisions not to

240. Such concepts have proliferated in the business law field and have included terms unfamiliar to most of the world's judiciary prior to the expansion of multilateral corporations. For example, franchising, factoring, and leasing were unknown in civil law systems, and those states have chosen to broadly adopt the common law (usually American) definition of these concepts. See Wiegand, supra note 9, at 236-38.

241. Smith, supra note 238, at 224.

242. Ugo Mattei, Why the Wind Changed: Intellectual Leadership in Western Law, 42 AM. J. COMP. L. 195 (1994).

243. Michael C. Dorf, The Hidden International Influence in the Supreme Court Decision Barring Executions of the Mentally Retarded, FindLaw's Writ (June 19, 2002), http://writ.news.findlaw.com/dorf/20020626.html (last visited May 1, 2005).

244. Slaughter, supra note 15.

245. "Ius Commune" is the name of the substantial body of law that much of Europe shared before the codification movement of the Napoleonic Codes. Sjef van Erp, lus Commune: A European Civil Code?, 4.4 ELEC. J. COMP. L. (Dec. 2000), http://www.ejcl.org/44/editor44.html (last visited May 1,2005 ). 
follow American jurisprudence on certain matters, as in $\mathrm{Hill} ;{ }^{246}$ the South African Court's rejection of many global precedents, as in Hugo, ${ }^{247}$ the Irish Court's repudiation of English law, as in Wyatt ${ }^{248}$ and the Indian Court's concern about relying on foreign law for more than "mere guidance" in Mehta $^{249}$ are all indicative of the differentiation possible even for courts that have increasingly relied on an internationalized domestic jurisprudence. Moreover, the sheer size of the international legal canon, and the consequent ability of judges to pick and choose cases, means that the mere reference to nonmunicipal law does not mean that the same decision will be reached by different judges. For example, in Roper $v$. Simmons, the 2005 case that struck down the juvenile death penalty in the U.S., Justice Kennedy's majority opinion and Justice O'Connor's dissent both used foreign law to argue contrary positions. ${ }^{250}$

Further, even if foreign law has a partially homogenizing role, such similarity may not mean that judicial orders as implemented will be the same across states. Legal systems reflect the cultures within which they are situated and thus have unique and highly contingent identities. Certain rights are clearly nationally defined, with categories such as "political speech" varying according to cultural history and national proclivities. In particular, the organic quality of the common law firmly embeds legal rights in local norms and customs. ${ }^{251}$ This suggests that even the same decisions rendered by judges explicitly protecting the same named rights or redressing the same named wrongs will likely differ in application on the ground. ${ }^{252}$ "Affirmative action" is a forceful example of the maintenance of deeper distinctions despite surface similarities. Despite the fact that affirmative action receives constitutional protection in both India and the U.S., and that both states profess the same reasons for the program's necessity, affirmative action is implemented in divergent-and potentially incompatible-manners in the two countries. ${ }^{253}$

246. Hill v. Church of Scientology of Toronto, [1995] 2 S.C.R. 1130.

247. President of the Republic of S. Afr. v. Hugo 1997 (4) SA 1 (CC) (S. Afr.).

248. Wyatt v. McLoughlin, [1974] I.R. 378 (Ir.).

249. In M.C. Mehta v. Union of India, Chief Justice Bhagwati argued: "[we] cannot allow our judicial thinking to be constricted by reference to the law as it prevails in England or for the matter of that in any other foreign country." A.I.R. 1987 S.C. 1086, 1099.

250. $125 \mathrm{~S}$. Ct. 1183 (2005). Justice Kennedy referred to "leading members of the Western European community," an emerging consensus in the global community, the UN Convention on the Rights of the Child (unsigned by the United States), and experiences in England. Id. at 1198-1200. Justice O'Connor, meanwhile, was willing to accept international precedent but refused to give it a "confirmatory" role in the Court's decisions. Id. at 1215 (O'Connor, J., dissenting).

251. See Vicki C. Jackson \& Mark Tushnet, Comparative CONSTitutional LaW: CASES AND MATERIALS 251-356 (1999).

252. Schauer, supra note 29, at 879-80; see also Alford, supra note 29, at 954 (discussing his hypothesis that words familiar to the U.S. Constitution found in the Chinese Constitution may mean different things because of their respective cultural contexts).

253. For example, India does not apply affirmative action to the "creamy layer" of subordinated groups, an idea explicitly rejected in the U.S. Compare Indra Sawhney v. Union of India, 80 A.I.R. 1993 S.C. 477, 558-60 (describing the constitutional necessity of the "creamy layer" doctrine) with Grutter v. Bollinger, 539 U.S. 306 (2003) and Gratz v. Bollinger, 539 U.S. 244 (2003). See also Mark Tushnet, Interpreting Constitutions Comparatively: Some Cautionary Notes, 
Though the actual outcome of how the use of foreign law will change domestic systems remains unclear, it is evident that the foreign law debatefrom the types of foreign law chosen, to the manner in which such law is considered, to the impact of such law on the ground-is far more complex than the arguments of most isolationists and internationalists seem to suggest. Viewed through the Indian experience, it is evident that the judiciary is only one player in the process, and that political and economic actors are critical both to the initial decision to use foreign law and the actual implementation of judicial orders that rely on foreign law. Further, the Indian case manifests the growing equivocation of fundamental terms in the debate: the nature of "foreign" and "domestic" are becoming less clear thanks to transnational legal regimes and "borderless" cultural and social environments.

The larger task of this essay is to try to reframe the debate and the issues regarding the use of foreign law in three ways. First, it is imperative that both sides of the discussion (in any jurisdiction in which it is occurring) acknowledge globalization, and concede that this phenomenon forces decisions on the judiciary, just as it compels behaviors in other parts of government and society. Second, given the inevitability of many of these globalizing changes, the language of the debate should change. In realms such as economics or politics, it is rare to know the national genealogy of a theory or idea, let alone to debate the importance of the place of its birth. The issue in such fields is not whether a concept is foreign or domestic, but rather whether it is reflective of good or bad reasoning. The law and legal precedents need to adopt this nationality "blindness." Allowing law to hide behind "foreign" or "domestic" labels misses the point of legal analysis - the goal of which is to provide the best possible reasoning for a given decision-and thus borders on being a category mistake. Finally, despite national differences in how foreign law impacts domestic culture, one aspect of foreign law usage seems likely to remain constant: effective use of foreign law requires an understanding of not just the laws themselves, but also their particular social, historical, and cultural contexts. It is not surprising that many academics who study comparative law are not only lawyers, but also sociologists, political scientists, or anthropologists. Most practicing lawyers, however, are trained solely in the law, and lack the interdisciplinary inclinations of their academic colleagues. Thus, while it seems clear that foreign law will inexorably increase as the world globalizes, it remains unclear whether today's lawyers and judges will be up to the task of most effectively using each other's experiences. ${ }^{254}$

with Reference to Affirmative Action, 36 CONN. L. REV. 649 (2004).

254. Martha Nussbaum, Introduction to Comparative Constitutionalism, 3 CHI. J. INT'L L. 429 (2002). 